\title{
Mineralogical and Geochemical Constraints on Magma Evolution and Late-Stage Crystallization History of the Breivikbotn Silicocarbonatite, Seiland Igneous Province in Northern Norway: Prerequisites for Zeolite Deposits in Carbonatite Complexes
}

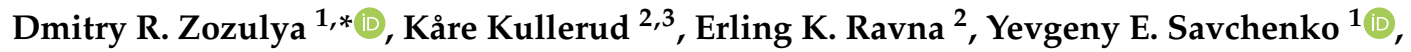 \\ Ekaterina A. Selivanova ${ }^{1}(\mathbb{D})$ and Marina G. Timofeeva ${ }^{1}$ \\ 1 Geological Institute, Kola Science Centre, 14 Fersman Str, 184209 Apatity, Russia; \\ evsav@geoksc.apatity.ru (Y.E.S.); selivanova@geoksc.apatity.ru (E.A.S.); marchim@mail.ru (M.G.T.) \\ 2 Department of Geology, University of Tromsø, N-9037 Tromsø, Norway; Kare.Kullerud@bvm.no (K.K.); \\ ekr001@post.uit.no (E.K.R.) \\ 3 Norwegian Mining Museum, N-3616 Kongsberg, Norway \\ * Correspondence: zozulya@geoksc.apatity.ru; Tel.: +7-81555-79742
}

Received: 22 September 2018; Accepted: 16 November 2018; Published: 20 November 2018

\begin{abstract}
The present work reports on new mineralogical and whole-rock geochemical data from the Breivikbotn silicocarbonatite (Seiland igneous province, North Norway), allowing conclusions to be drawn concerning its origin and the role of late fluid alteration. The rock shows a rare mineral association: calcite + pyroxene + amphibole + zeolite group minerals + garnet + titanite, with apatite, allanite, magnetite and zircon as minor and accessory minerals, and it is classified as silicocarbonatite. Calcite, titanite and pyroxene $\left(\mathrm{Di}_{36-46} \mathrm{Acm}_{22-37} \mathrm{Hd}_{14-21}\right)$ are primarily magmatic minerals. Amphibole of mainly hastingsitic composition has formed after pyroxene at a late-magmatic stage. Zeolite group minerals (natrolite, gonnardite, Sr-rich thomsonite-(Ca)) were formed during hydrothermal alteration of primary nepheline by fluids/solutions with high Si-Al-Ca activities. Poikilitic garnet (Ti-bearing andradite) has inclusions of all primary minerals, amphibole and zeolites, and presumably crystallized metasomatically during a late metamorphic event (Caledonian orogeny). Whole-rock chemical compositions of the silicocarbonatite differs from the global average of calciocarbonatites by elevated silica, aluminium, sodium and iron, but show comparable contents of trace elements (REE, Sr, Ba). Trace element distributions and abundances indicate within-plate tectonic setting of the carbonatite. The spatial proximity of carbonatite and alkaline ultramafic rock (melteigite), the presence of "primary nepheline" in carbonatite together with the trace element distributions indicate that the carbonatite was derived by crystal fractionation of a parental carbonated foidite magma. The main prerequisites for the extensive formation of zeolite group minerals in silicocarbonatite are revealed.
\end{abstract}

Keywords: silicocarbonatite; melteigite; calcite; nepheline; zeolite group minerals; garnet; crystal fractionation; Breivikbotn; Northern Norway

\section{Introduction}

Alkaline rocks and carbonatites represent less than 1\% of all igneous rocks of the Earth's crust. However, the petrogenesis of these rocks is particularly interesting, in part due to their great variability and in part because they are economically important, containing most of the global reserves of, 
for example, rare earth elements (REE), zirconium, niobium and phosphorus (apatite). Moreover, alkaline igneous rocks and carbonatites have great petrological and geodynamical significances. Most common point of view for their generation is low-volume partial melting of mantle domains enriched in trace elements and volatiles. Owing to their deep source and rapid ascent to the crust, the rocks of this clan bear information on the composition of the deep Earth. Combining observations on the geochemical characteristics of natural rocks with experimental results may provide insight into processes of mantle metasomatism and melt generation in high-pressure conditions. Metasomatism by carbonatite melts has been recognized as an important mechanism for enrichment of mantle domains.

Although it has long been recognized that alkaline rocks occur in various tectonic settings worldwide, study of these rocks, particularly carbonatites, has focused mainly on within-plate continental rift environments. Due to the typically low volume and high reactivity of these magmas, it may nonetheless be assumed that an extensional tectonic environment is prerequisite to their emplacement into the upper crust. In post-collisional extensional settings, alkaline rocks and carbonatites have the potential to provide information about the effects of convergent tectonic processes on the geochemical evolution of the upper mantle. Although the majority of known carbonatites are found in rift or near-rift settings, they may rarely occur in off-craton settings where extension may be localized in back-arc regimes or as a consequence of widespread orogenic collapse [1]. Nevertheless, recently, the carbonatites in pure collisional and subduction tectonic settings were reported from several localities worldwide [2-6]. Enrichment in high field strength elements (HFSE) such as niobium and zirconium, once considered an essential characteristic of within-plate carbonatite, is conspicuously absent from carbonatites in collisional and subduction tectonic settings. Furthermore, carbonatite melts in within-plate setting are highly reactive and cause alkaline metasomatic alteration (fenitization) of the surrounding rocks [7].

In this paper, new geochemical and mineralogical data on the Breivikbotn carbonatite are presented and its possible origin and late-, post-crystallization processes are proposed. The occurrence is remarkable for the high zeolite content, and the main prerequisites for zeolite formation in carbonatite complexes are substantiated.

\section{Geological Setting}

\subsection{Seiland Igneous Province}

The Seiland Igneous Province (SIP) consists of contemporaneous mafic, ultramafic, intermediate, granitic and alkaline intrusions emplaced into a $50 \times 100-\mathrm{km}$ area 570-560 Ma ago. These intrusions are constrained to a single nappe within the Kalak Nappe complex of Northern Norway. This nappe complex has been generally assumed to be a parautochthonous terrane within the $420 \mathrm{Ma}$ Norwegian Caledonides [8], but more recent work has indicated that the terrane may be exotic and allochthonous [9]. The largest portion of the SIP consists of numerous mafic plutons, commonly layered, which comprise at least $50-60 \%$ of the province. Large ultramafic complexes comprise a further $25-35 \%$ of the complex, while intermediate rock types such as monzonite and diorite make up $10 \%$. Alkaline intrusions occur throughout the province, covering about $5 \%$ of the area. Granitic rocks are restricted to a few small, insignificant bodies on Øksfjord and Sørøy.

Sturt et al. [10] and Ramsay and Sturt [11] suggested that the magmatic activity in the SIP was synorogenic and related to the "Finnmarkian Orogeny", an early phase of the Caledonian Orogeny. This was based on field observations suggesting that the foliated igneous rocks were cut by younger intrusions that in turn were overprinted by a later metamorphic fabric. According to Sturt and Ramsay [12] and Sturt et al. [10], the late stage alkaline rocks in the province were both intruded and deformed during the youngest phase of the Finnmarkian deformation in the Sørøy Nappe. Krill and Zwaan [13] re-evaluated the field relationships in Sørøy and suggested that the igneous rocks of SIP were preorogenic, rather than synorogenic. They proposed that the magmatic activity was related to crustal attenuation and rift formation along the margin of Fennoscandia. Based on new U-Pb 
zircon ages from SIP, Roberts et al. [14] proposed an extensional setting for SIP and interpreted the younger ages (460-420 Ma) as evidence for superimposed metamorphism during the main stages of the Caledonian orogeny.

\subsection{Breivikbotn Carbonatite}

This complex consists of carbonatite, malignite (named shonkinite [12]), nepheline syenite, aplitic syenite and pyroxenite. It occurs as a deformed, $2 \mathrm{~km}$ long and $500 \mathrm{~m}$ wide sill hosted within the Klubben Psammite, a metasedimentary unit of the Kalak Nappe Complex [15]. At the northern side of the bay at Haraldseng, the carbonatite has intruded one limb of a N-S-trending fold, and stands out clearly in contrast to the surrounding layered sediments. Single layers of the intrusion extend north-south, with the eastern edge marked by a thin $(<10 \mathrm{~m})$ aegirine-augite pyroxenite body, which appears to lie conformably on the steeply dipping psammites. Some shearing has taken place along this contact, but there is nothing to contradict the conclusion that this is the bottom contact of the intrusion [12]. The pyroxenite, like the rest of the complex, is intruded by numerous centimetre-thick nepheline syenite and dolerite dykes, and is extremely variable in appearance.

Overlying the pyroxenite, across a thin band of carbonatitic breccia, there is a coarse-grained malignite, dominated by feldspar, but also containing pyroxene (aegirine-augite) and amphibole. Some localities are rich in melanitic garnet [15]. Malignite from the Breivikbotn complex can be divided in two varieties based on the dominant mafic mineral. The most common type is rich in melanite and the other type is rich in clinopyroxene. Both types occur within the central parts of the Breivikbotn complex. Present are also zeolites (pseudomorphosed after nepheline; [15]), calcite, titanite and zircon. Melanite (up 30-70 modal \%), pyroxene (40-60 modal \%), feldspar (10-40 modal \%, in parts absent) and "nepheline" are obviously magmatic minerals. In less deformed malignite, melanite shows oscillatory zoned crystals. The zoning is characterized by an alternation of light- and dark-brown zones, probably reflecting variations in the Ti-content (overall, the $\mathrm{TiO}_{2}$ content in garnet varies from 2.1 to $4.1 \mathrm{wt} \%$ [15]). Commonly, melanite shows dark central parts and lighter marginal parts. The crystals are euhedral, and may be overgrown by later garnet. Characteristic for melanite is the presence of inclusions of zeolite aggregates. Furthermore, melanite is overgrown by clinopyroxene, which in turn is overgrown by amphibole. Clinopyroxene occurs as prismatic, subhedral to euhedral crystals. The size of the crystal varies; they can be up to $3 \mathrm{~cm}$ long. Inclusions of titanite, calcite and an opaque mineral are observed. In addition, grains are observed. Pyroxene is often overgrown by amphibole and light yellow garnet. In places, clinopyroxene has both inclusions, and a rim of amphibole. Pyroxene is occasionally observed as inclusions in melanite. Based on its optical properties, in addition to mineral chemical analyses [15], it is assumed that the mineral is aegirine-augite. To our opinion, the petrography (particularly, the presence of garnet and low modal content of nepheline) of this rock does not fit well to s.s. malignite and below the term "malignite" is used.

The "malignite" has a banded appearance, caused by changes in grain-size and mineralogy. The underlying carbonatitic breccia comprises a network of thin carbonatite veins enclosing large angular fragments of both "malignite" and pyroxenite, and generally sheared along the edges.

"Malignite" intrudes alkali pyroxenite, which can also be observed as inclusions in the "malignite». The "malignite" has been carbonatized, and it is cross-cut by $4-5 \mathrm{~cm}$ thick carbonate veins. "Malignite" also occurs as xenoliths in the carbonatite. The «malignite» grades into carbonatite, with no clear boundary between the two rock types. The carbonatite is very variable in both texture and composition, and generally occurs as sheets. In some layers, particularly at the top of the intrusion, the carbonatite contains fragments of country rock [12]. At the top of the intrusion the carbonatite truncates the sedimentary banding in the psammites, but there is a ubiquitous metasomatic alteration $[12,15]$.

Nepheline syenite occurs mainly as thin carbonated dykes but seems to develop into a more extensive unit further north [15]. It commonly contains biotite, or locally clinopyroxene. The nepheline syenite is often foliated and has extremely variable nepheline and carbonate contents that allow interpreting it as a product of alkaline metasomatism (fenitization) of aplitic syenite. 
The dolerite dykes are apparently the last magmatic event. They intrude the carbonatite in numerous sites, and somewhere folded and boudinaged.

\section{Analytical Methods}

\subsection{Mineral Analyses}

The chemical compositions of minerals from the carbonatite were carried out at the Geological Institute, Kola Science Centre, by means of an electron microprobe Cameca MS-46, Cameca, Paris, France (WDS mode, $22 \mathrm{kV}, 30-40 \mathrm{nA}$, with $50 \mathrm{~s}$ counting time). The following calibrating materials (and analytical lines) were used: wollastonite $(\mathrm{SiK} \alpha, \mathrm{CaK} \alpha)$, hematite $(\mathrm{Fe} K \alpha)$, apatite $(\mathrm{P} K \alpha)$, lorenzenite $(\mathrm{NaK} \alpha)$, thorite $(\mathrm{Th} M \alpha), \mathrm{MnCO}_{3}(\mathrm{MnK} \alpha), \mathrm{Y}_{3} \mathrm{Al}_{5} \mathrm{O}_{12}(\mathrm{Y} L \alpha),(\mathrm{La}, \mathrm{Ce}) \mathrm{S}(\mathrm{La} L \alpha), \mathrm{CeS}(\mathrm{Ce} L \alpha)$, $\mathrm{Pr}_{3} \mathrm{Al}_{5} \mathrm{O}_{12}\left(\operatorname{Pr} L \beta_{1}\right), \mathrm{LiNd}\left(\mathrm{MoO}_{4}\right)_{2}(\mathrm{Nd} L \alpha), \mathrm{SmFeO}_{3}(\mathrm{SmL} \alpha), \mathrm{EuFeO}_{3}(\mathrm{Eu} L \alpha), \mathrm{GdS}(\mathrm{Gd} L \alpha), \mathrm{TbPO}_{4}$ $(\mathrm{Tb} L \alpha), \mathrm{Dy}_{3} \mathrm{Al}_{5} \mathrm{O}_{12}(\mathrm{Dy} L \alpha), \mathrm{Ho}_{3} \mathrm{Ga}_{5} \mathrm{O}_{12}\left(\mathrm{HoL} \beta_{1}\right), \mathrm{ErPO}_{4}(\mathrm{Er} L \alpha), \mathrm{Tm}_{3} \mathrm{Al}_{5} \mathrm{O}_{12}(\operatorname{Tm} L \alpha), \mathrm{Yb}_{3} \mathrm{Al}_{5} \mathrm{O}_{12}(\mathrm{Yb} L \alpha)$, and $\mathrm{Y}_{2.8} \mathrm{Lu}_{0.2} \mathrm{Al}_{5} \mathrm{O}_{12}(\mathrm{LuL} \alpha)$. Detection limits for $\mathrm{Fe}, \mathrm{Mn}$ are $0.01 \% ; \mathrm{Si}, \mathrm{Al}, \mathrm{Cl}, \mathrm{Ca}, \mathrm{K}, \mathrm{Cl}-0.02 \% ; \mathrm{P}, \mathrm{Na}, \mathrm{Y}$, $\mathrm{Sr}, \mathrm{La}, \mathrm{Ce}, \mathrm{Nd}-0.03 \%$; $\mathrm{Ba}-0.05 \% ; \mathrm{Nb}, \mathrm{Zr}-0.1 \%$. Representative electron microprobe data for minerals are given in Tables $1-4$.

The accessory mineral identification was performed using a LEO-1450 SEM (scanning electron microscope, Carl Zeiss AG, Oberkochen, Germany) equipped with XFlash-5010 Bruker Nano GmbH EDS (energy-dispersive X-ray spectroscopy, Bruker Nano GmbH, Berlin, Germany). The system was operated at $20 \mathrm{kV}$ acceleration voltage, $0.5 \mathrm{nA}$ beam current, with $200 \mathrm{~s}$ accumulation time.

Materials from small areas of zeolite group minerals close to points analysed by microprobe were examined by the X-ray powder diffraction (XRPD) method (Debye-Scherer) by means of an URS-1 operated at $40 \mathrm{kV}$ and $16 \mathrm{~mA}$ with RKU-114.7 mm camera and FeK $\alpha$-radiation.

\subsection{Whole-Rock Analyses}

Whole-rock composition data for carbonatite-like rock were obtained at the Kola Science Centre in Apatity, Russia. Most of the major elements were determined by atomic absorption spectrophotometry; $\mathrm{TiO}_{2}$ by colorimetry; $\mathrm{K}_{2} \mathrm{O}$ and $\mathrm{Na}_{2} \mathrm{O}$ by flame photometry; $\mathrm{FeO}$ and $\mathrm{CO}_{2}$ by titration (volumetric analysis); and $\mathrm{F}$ and $\mathrm{Cl}$ by potentiometry using an ion-selective electrode (for a description of the methods, see [16]). Trace elements were determined by Inductively Coupled Plasma-Mass Spectrometry on a PerkinElmer Elan 9000 DRC-e (PerkinElmer Inc., Waltham, MA, USA).

The additional whole-rock composition data for the carbonatite-like and alkaline rocks from the occurrence were obtained at the Department of Biology and Geology, University of Tromsø. Two parallels of each sample were analyzed for major, minor and trace elements by $\mathrm{X}$-ray fluorescence (XRF) on a Philips PW 1400 instrument (Philips, Amsterdam, The Netherlands). For major and minor elements analyses, fused pellets containing a mixture of rock powder and lithium tetraborate flux were used (mixed in ratio of 1:6). Trace element analyses were carried out on pressed powder pellets. The calibration of the analytical instrument was checked against the international standards GH, GM and NIM-S [17].

Major and minor element compositions of selected samples are presented in Table 5, and trace elements in Table 6. The whole dataset is presented in the Supplementary Data Table S1.

\section{Petrography and Mineral Compositions: Results and Interpretation}

The Breivikbotn carbonatite is a massive rock of porphyritic texture with hypidiomorphic, lesser idiomorphic phenocrysts of garnet and pyroxene. The groundmass is medium and coarse grained and composed of carbonate, pyroxene, amphibole and zeolite. The textural relationships of the studied samples are shown on Figure 1 . The mineral content is variable and consists of carbonate (20-50 vol. \%), amphibole (5-20 vol. \%), pyroxene (5-20 vol. \%), zeolite group minerals ( $0-20$ vol. \%), garnet ( $0-30$ vol. \%). Minor and accessory minerals are apatite (1-3 vol. \%), titanite (1-5 vol. \%), allanite, magnetite, zircon, pyrite, pyrrhotite, chalcopyrite, scheelite, celestine, barite, and baddeleyite. 
In several thin sections, single grains of quartz were observed. Its interstitial character points on deuteric nature.

The relationships between different minerals and their internal structure are shown on Figures 2-4. Chemical analyses for major and accessory minerals are given in Tables $1-4$ and in text.
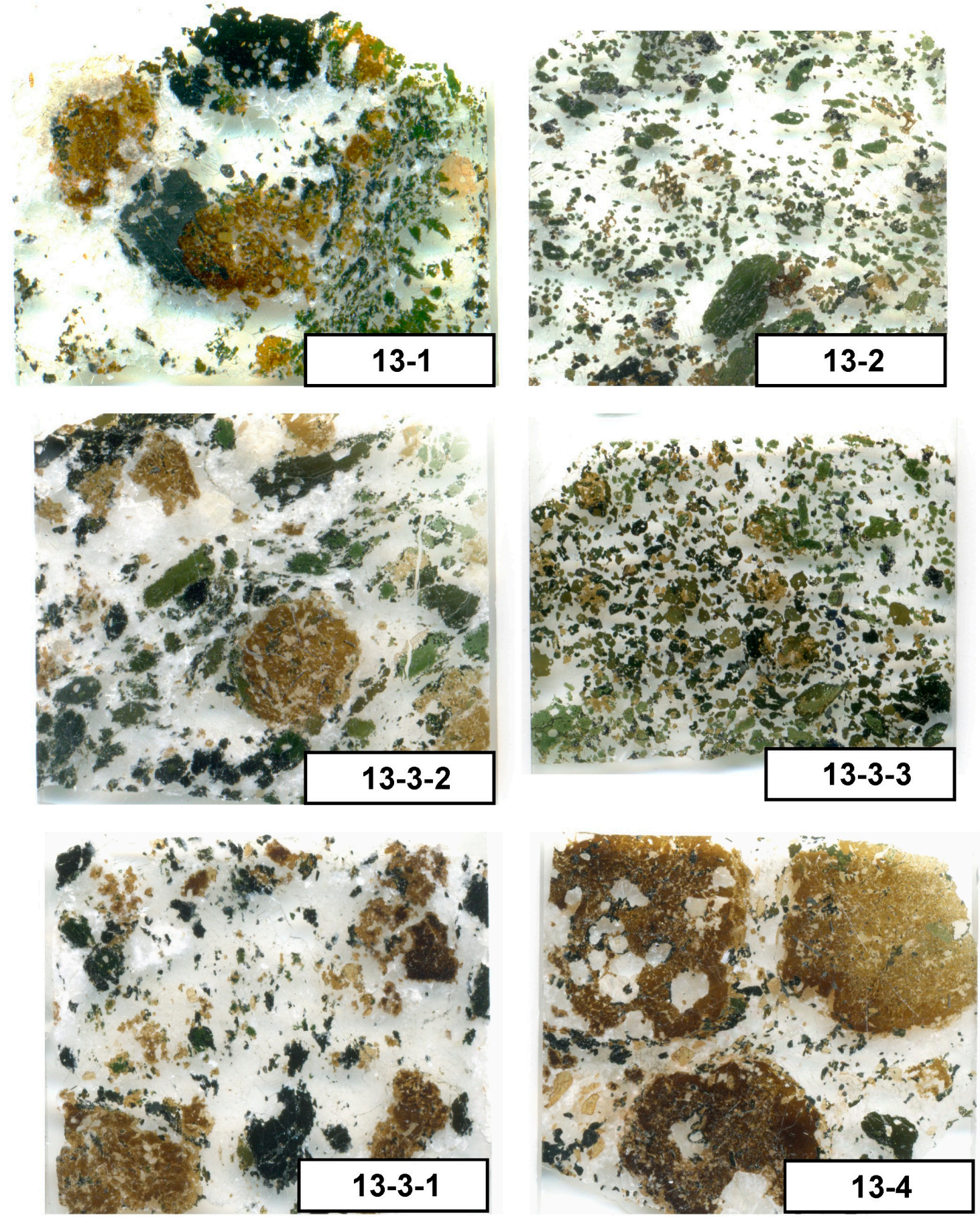

Figure 1. Scans of the selected samples of the Breivikbotn carbonatite, showing extremely heterogeneous textures. Carbonate and zeolite group minerals (white and transparent) form the groundmass; garnet (dark brown) forms rounded poikilitic grains; titanite (yellow) forms small angular and elongated euhedral crystals, pyroxene (greenish) forms subhedral and euhedral crystals, amphibole (bluish, dark-green, and indigo) forms anhedral grains and large laths. Width of all of the scans is about $2.5 \mathrm{~cm}$. 
Carbonate is clearly a primary mineral as it forms euhedral and subhedral crystals of $0.15-5 \mathrm{~mm}$ size with triple junctions between grains (Figure 2c). The carbonate is calcite (average formulae $\left(\left(\mathrm{Ca}_{0.953} \mathrm{Sr}_{0.014}\right.\right.$ $\left.\mathrm{Mn}_{0.003} \mathrm{Fe}_{0.002} \mathrm{Mg}_{0.001}\right)_{0.973} \mathrm{CO}_{3}$ ) with negligible contents of $\mathrm{Mg}$, Fe, and $\mathrm{Mn}$ (Table 1). Calcite contains elevated $\mathrm{SrO}$ (up to $2.15 \mathrm{wt} \%$ ) that is characteristic of magmatic calcite from carbonatites.

Pyroxene occurs as subhedral grains $0.3-4 \mathrm{~mm}$ in size, rarely as phenocrysts up to $1 \mathrm{~cm}$ in size. Pyroxene rims are often resorbed, and amphibole growth along the rims is observed. Pyroxene contains calcite inclusions. Representative compositions of pyroxene are given in Table 2. Compositionally, pyroxene shows a high content of the diopside component, with increased quantities of acmite and hedenbergite $\left(\mathrm{Di}_{36-46} \mathrm{Acm}_{22-37} \mathrm{Hd}_{14-21}\right)$. The average formula is $\left(\mathrm{Ca}_{0.75} \mathrm{Na}_{0,27}\right)_{1,02}\left(\mathrm{Mg}_{0.42} \mathrm{Fe}^{3+}{ }_{0.27} \mathrm{Fe}^{2+}{ }_{0.20} \mathrm{Al}_{0.07} \mathrm{Ti}_{0.02}\right)_{0.98}\left[\mathrm{Si}_{1.9} \mathrm{Al}_{0.1} \mathrm{O}_{6}\right]$. Pyroxene always shows minor content of $\mathrm{TiO}_{2}$ (up to $1 \mathrm{wt} \%$ ).

Amphibole occurs as anhedral and subhedral grains of $0.3-5 \mathrm{~mm}$ size. The mineral occurs as individual grains and as overgrowths on pyroxene (Figure 2b). Rarely, amphibole forms up to $1 \mathrm{~cm}$ poikilitic grains with inclusions of calcite and pyroxene. Amphibole is mainly hastingsitic with an essential proportion of magnesiohastingsite, rarely mineral is closed to taramite and sadanagaite groups (sample 13-4, see Table 2). The average formula is $\left(\mathrm{Na}_{0.88} \mathrm{~K}_{0.43}\right)_{1.31}\left(\mathrm{Ca}_{1.68} \mathrm{Na}_{0.14} \mathrm{Fe}^{2+}{ }_{0.18}\right)_{2}$ $\left(\mathrm{Ti}_{0.15} \mathrm{Fe}^{2+}{ }_{2.73} \mathrm{Mg}_{1.56} \mathrm{Al}_{0.43} \mathrm{Mn}_{0.12}\right)_{4.99}\left[\mathrm{Si}_{6.1} \mathrm{Al}_{1.9} \mathrm{O}_{23}\right]$. The mineral shows elevated contents of $\mathrm{K}_{2} \mathrm{O}$ $(2-2.3 \mathrm{wt} \%)$ and $\mathrm{TiO}_{2}(1.2-1.4 \mathrm{wt} \%)$. Fluorine and $\mathrm{Cl}$ are below detection limit.

Garnet usually occurs as porphyritic subhedral rounded grains of $0.5-1 \mathrm{~cm}$ size. The mineral has poikilitic texture and contains inclusions of calcite, pyroxene, amphibole, titanite, zeolite group minerals (Figure 2a,d,f and Figure 4). Rims of garnet overgrowing amphibole can also be observed (Figure 2c). Garnet is patchy-zoned; in BSE images, garnet is generally bright along the rims, with darker central parts, however, patches of bright garnet are also observed within the darker central parts (Figure 2a). The bright patches appear to reflect elevated Fe contents. Garnet texture and morphology suggest porphyroblastic growth. Representative chemical compositions are given in Table 3. Garnet can be classified as Ti-bearing andradite with the average formula $\left(\mathrm{Ca}_{2.90} \mathrm{Na}_{0.01} \mathrm{Y}_{0.01}\right)_{2.92}\left(\mathrm{Fe}^{3+}{ }_{1.50} \mathrm{Al}_{0.3} \mathrm{Ti}_{0.15} \mathrm{Mn}_{0.09} \mathrm{Mg}_{0.03} \mathrm{Zr}_{0.02}\right)_{2.1}\left[\mathrm{Si}_{2.91} \mathrm{Al}_{0.09} \mathrm{O}_{12}\right]$. The mineral contains $\mathrm{V}$, $\mathrm{Zr}$ and $\mathrm{Y}$ as minor constituents. The content of $\mathrm{TiO}_{2}$ varies in the range of $1.3-3.2 \mathrm{wt} \%$, which is low compared to titaniferous garnets from carbonatites and alkaline rocks ( $>5 \mathrm{wt} \%$, according to [18-22], and even lower than for melanite from the «malignite» from the Breivikbotn occurrence.

Zeolite group minerals and "altered nepheline". Clusters of zeolite group minerals (ZGM) have a stubby rectangular or equant rounded (roughly hexagonal) form, up to 2-3 $\mathrm{mm}$ in diameter (Figures 2-4). Most clusters are composed of natrolite and gonnardite; natrolite often occurs in the central parts of gonnardite aggregates, and it is inferred that natrolite is the earliest phase (Figure 3e,f).

Natrolite forms colourless, white, smooth anhedral grains of 1-2 mm size. The average chemical composition of natrolite, $\mathrm{Na}_{1.98} \mathrm{Ca}_{0.03} \mathrm{Si}_{3.01} \mathrm{Al}_{1.98} \mathrm{O}_{10} \cdot 2 \mathrm{H}_{2} \mathrm{O}$ (Table 4 ), is very close to the stoichiometric formula $\left(\mathrm{Na}_{2}\left(\mathrm{Si}_{3} \mathrm{Al}_{2}\right) \mathrm{O}_{10} \cdot 2 \mathrm{H}_{2} \mathrm{O}\right.$, IMA-list 09-2017). The $\mathrm{Si} /(\mathrm{Si}+\mathrm{Al})$ ratio varies from 0.57 to 0.65 , while sodium is in the range 1.81-2.22 apfu and calcium does not exceed 0.1 apfu.

Gonnardite occurs as colourless, uneven, cracky aggregates up to $1-3 \mathrm{~mm}$ in size, the individual grains are anhedral and $100-500 \mu \mathrm{m}$ in diameter. The average composition of gonnardite is calculated as $\left(\mathrm{Na}_{1.57} \mathrm{Ca}_{0.38}\right)_{2.05}\left(\mathrm{Si}_{2.67} \mathrm{Al}_{2.38}\right)_{5.05} \mathrm{O}_{10} \cdot 3 \mathrm{H}_{2} \mathrm{O}$, which is close the stoichiometric formula $\left((\mathrm{Na}, \mathrm{Ca})_{2}(\mathrm{Si}, \mathrm{Al})_{5} \mathrm{O}_{10} \cdot 3 \mathrm{H}_{2} \mathrm{O}\right.$, IMA-list 09-2017). The $\mathrm{Si} /(\mathrm{Si}+\mathrm{Al})$ ratio varies from 0.52 to 0.54 , while $\mathrm{Na} /(\mathrm{Na}+\mathrm{Ca})$ is from 0.76 to 0.85 .

Thomsonite-(Ca) forms colourless and white rectangular grains (Figure 3d). It is irregularly zoned, and in BSE images characterized by brighter and darker zones. The mineral appears as partly fibrous. The average composition is $\mathrm{Na}_{1.13} \mathrm{Ca}_{1.7}\left(\mathrm{Al}_{4.98} \mathrm{Si}_{5.1}\right) \mathrm{O}_{20} \cdot 6 \mathrm{H}_{2} \mathrm{O}$, which is close to ideal formula $\left(\mathrm{NaCa}_{2}\left(\mathrm{Al}_{5} \mathrm{Si}_{5}\right) \mathrm{O}_{20} \cdot 6 \mathrm{H}_{2} \mathrm{O}\right.$, IMA-list 09-2017). The mineral is characterized by elevated Sr content (0.02-0.34 apfu, with average $0.09 \mathrm{apfu})$. The Sr content may vary within a single crystal as indicated by the brighter and darker zones in BSE images. The $\mathrm{Si} /(\mathrm{Si}+\mathrm{Al})$ ratio varies from 0.49 to 0.52 , while $\mathrm{Na} /(\mathrm{Na}+\mathrm{Ca}+\mathrm{Sr})$ varies from 0.34 to 0.42 . 
Overall, the ZGM of Breivikbotn carbonatite show successively increasing Ca and Al contents from natrolite, through gonnardite to thomsonite-(Ca).
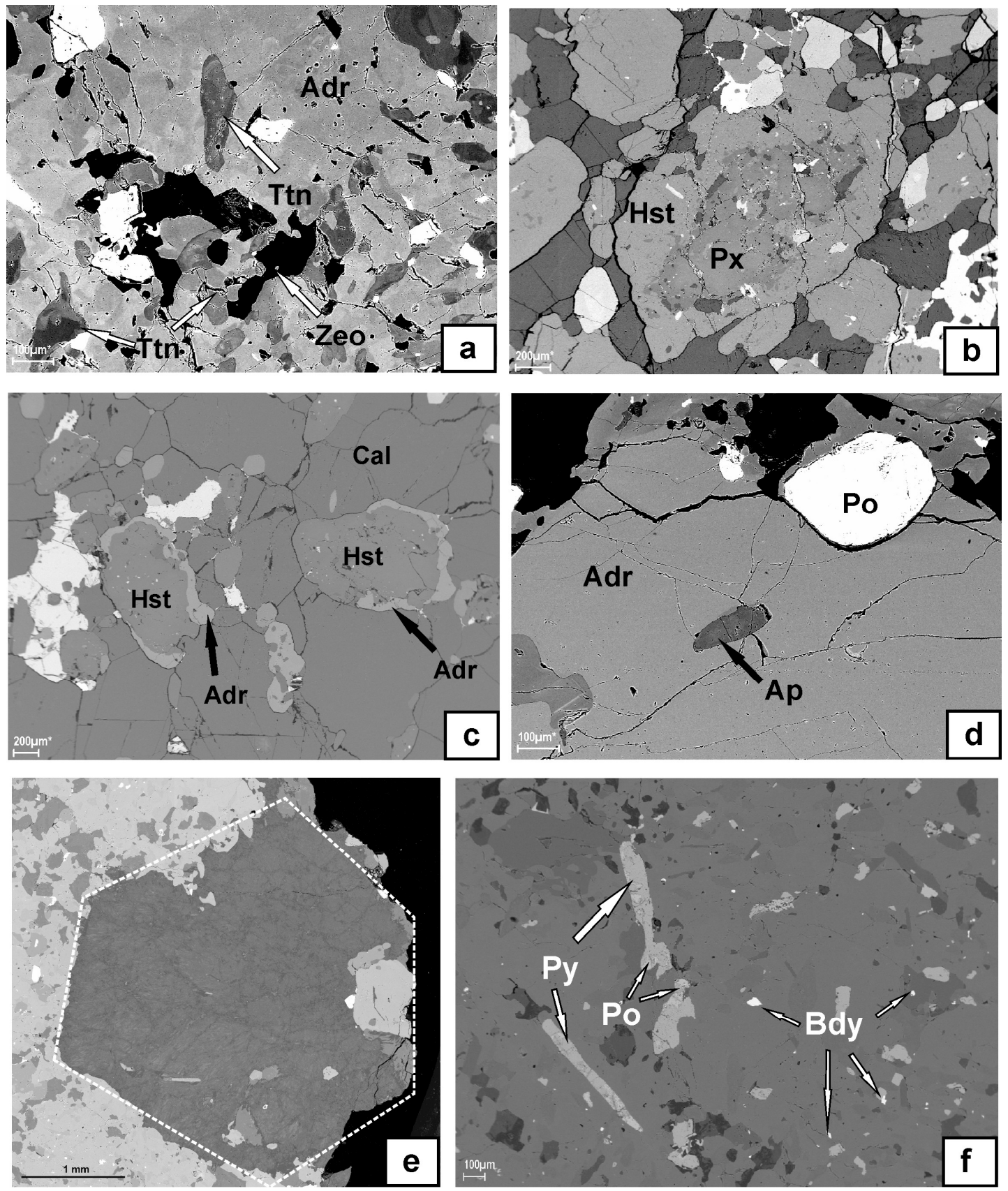

Figure 2. Back-scattered-electron (BSE) images showing the relationships between different minerals in the Breivikbotn carbonatite: (a) titanite, zeolite and magnetite (brightest) included in andradite; (b) hastingsite rimming pyroxene; (c) andradite rim around hastingsite, calcite grains show typical triple junctions; (d) apatite and pyrrhotite included in andradite; (e) roughly hexagonal habit of zeolite aggregate; (f) inclusions of accessory pyrite, pyrrhotite and baddeleyite in andradite. Mineral abbreviations are from [23].

In some natrolite-gonnardite clusters, water-absent $\mathrm{Na}-\mathrm{Al}$ silicates with chemical compositions close to nepheline were found (Table 4). These compositions in combination with the textural appearance of the natrolite-gonnardite aggregates suggest that the aggregates are pseudomorphs after nepheline. Thomsonite-(Ca) can also be inferred as an alteration product of nepheline. 
The water-absent nepheline-like mineral is characterized by compositions corresponding to $\mathrm{Na}_{0.53-0.7} \mathrm{Ca}_{0.01-0.16} \mathrm{Al}_{1.07-1.24} \mathrm{Si}_{1.06-1.22} \mathrm{O}_{4}$, which is somewhat different from the stoichiometric formula of nepheline, with lower $\mathrm{Na}$ and higher $\mathrm{Ca}$. We suppose that the mineral initially crystallized as nepheline from a carbonatite magma, and subsequently underwent alteration in a high-Ca environment. Ca-bearing and Ca-rich nephelines have been found in alkaline rocks from the Messum complex, Namibia [24], from the Marangudzi Complex, Zimbabwe [25], and from the Allende meteorite [26,27].

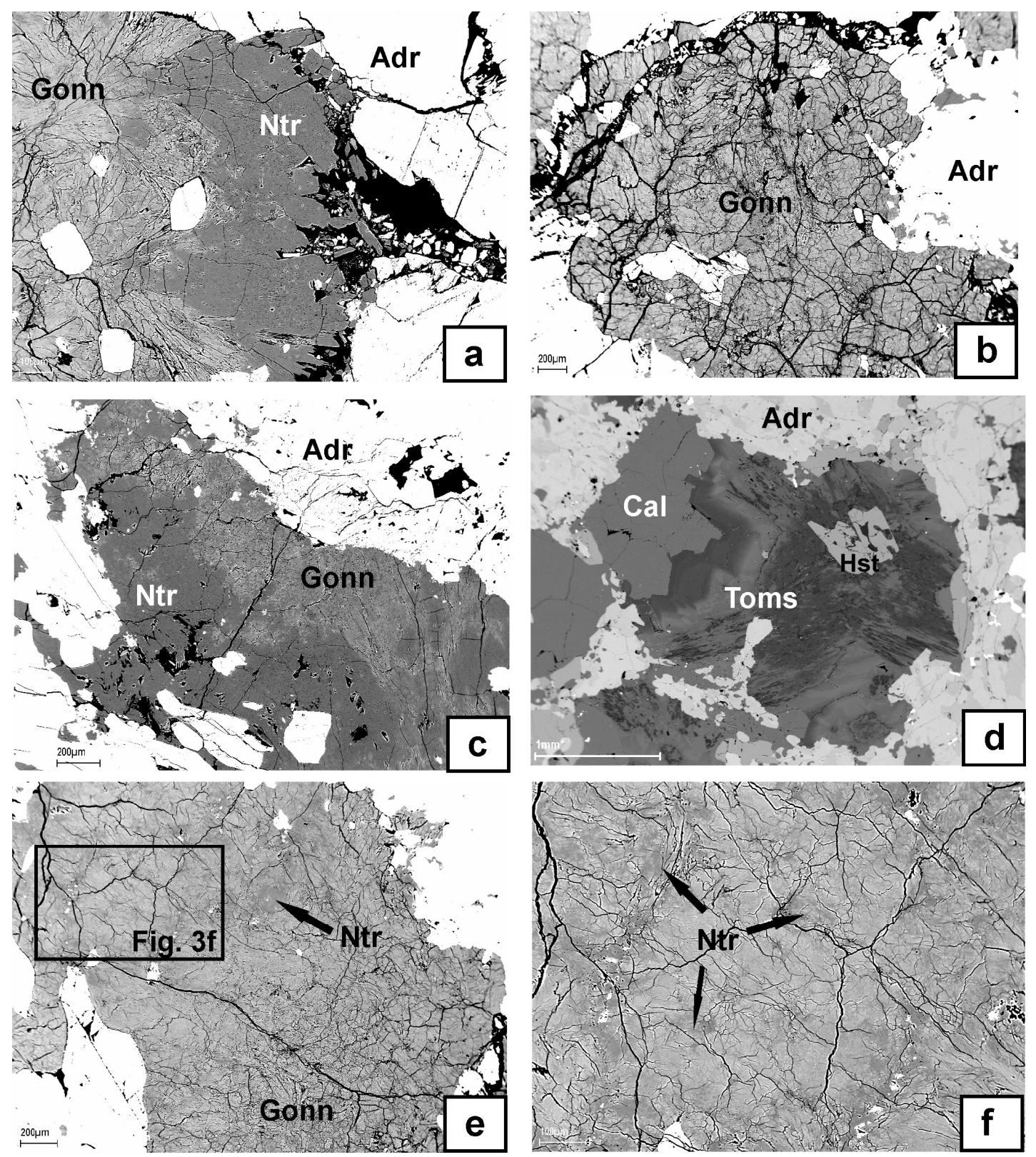

Figure 3. BSE images showing the morphology and internal textures of zeolite group minerals: $(\mathbf{a}-\mathbf{c})$ intergrowths and aggregates of natrolite and gonnardite; (d) zonal structure of thomsonite-(Ca) with low (dark gray) and high (gray) Sr content; (e,f) "shadow"-type domains of natrolite (dark-gray) in gonnardite (light-gray), illustrating the early crystallization of natrolite relative to gonnardite (XRPD of the sample indicated a mix of both minerals). Mineral abbreviations are from [23]. Toms-thomsonite-(Ca), Gonn-gonnardite.

Titanite occurs as euhedral and subhedral elongated grains. It is often associated with garnet, i.e., included in garnet and occurring adjacent to garnet. The average chemical composition of titanite is 
$\left(\mathrm{Ca}_{0.97} \mathrm{Y}_{0.01} \mathrm{Ce}_{0.01}\right)\left(\mathrm{Ti}_{0.93} \mathrm{Fe}_{0.05} \mathrm{Zr}_{0.01} \mathrm{Nb}_{0.01}\right)\left(\mathrm{Si}_{0.97} \mathrm{Al}_{0.04} \mathrm{O}_{5}\right)$. Titanite shows elevated contents of REE, $\mathrm{Zr}, \mathrm{Nb}, \mathrm{Fe}$ and $\mathrm{Al}$. Incorporation of iron and aluminium in the titanite structure requires the coupled substitutions: $\mathrm{Ti}^{4+}+\mathrm{O}^{2-}=\left(\mathrm{A} 1, \mathrm{Fe}^{3+}\right)+(\mathrm{F}, \mathrm{OH})^{-}$and takes place at high-P metamorphic conditions [28].

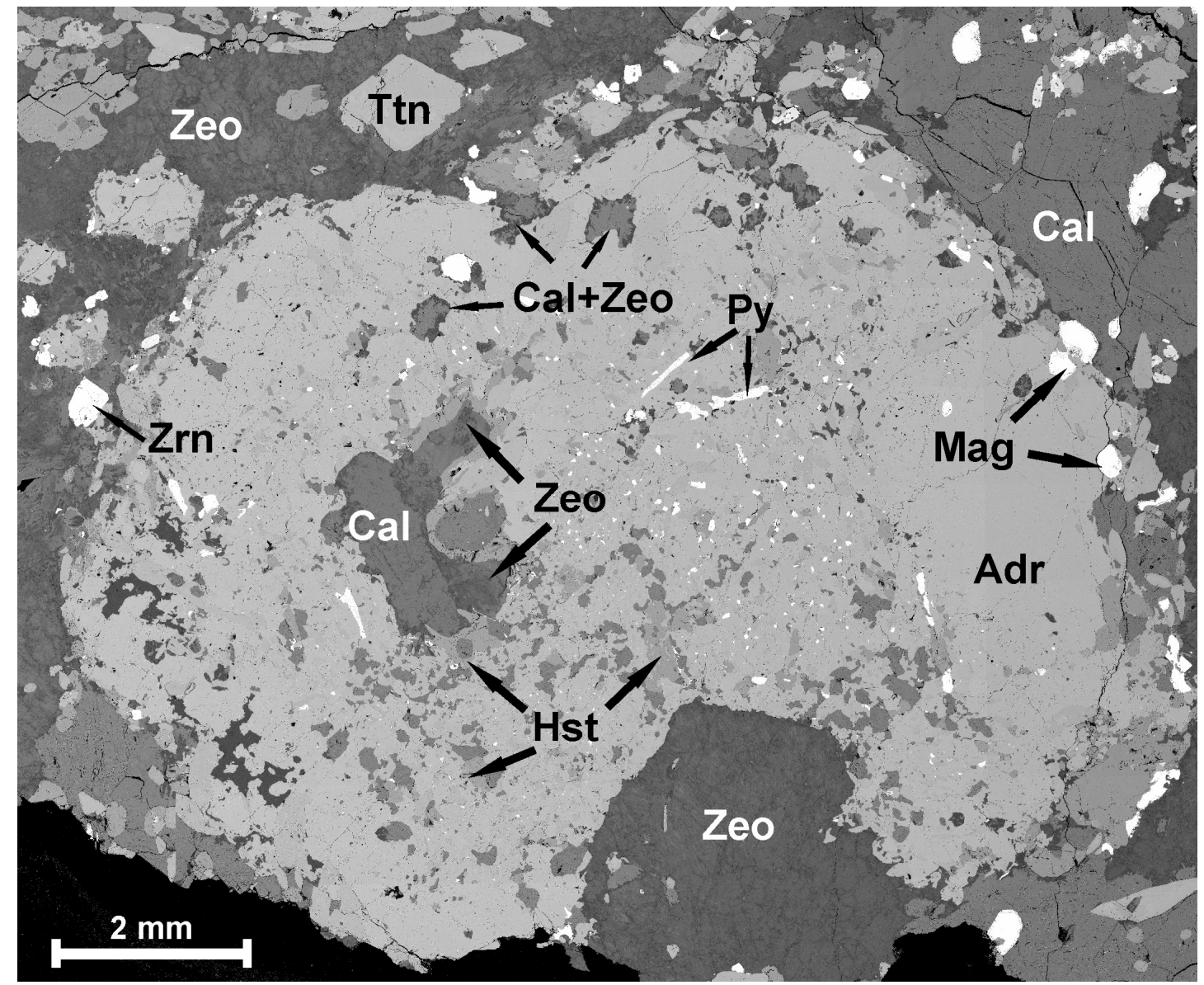

Figure 4. BSE image of typical poikilitic andradite with inclusions of calcite, hastingsite, zeolites, magnetite and pyrite. Zeolites often form intergrowths and aggregates of rectangular shape (bottom). A large number of tiny grains of baddeleyite (bright grains, $\leq 50 \mu \mathrm{m}$ ) occur in the central part of the andradite grain. Mineral abbreviations are from [23]. The image is a mosaic of 160 small $1.2 \times 0.8 \mathrm{~mm}$ BSE images.

Table 1. Representative chemical compositions and mineral formulae of carbonate from the Breivikbotn carbonatite.

\begin{tabular}{cccc}
\hline Sample No. & $\mathbf{1 3 - 4 - 1 - 5 - 1}$ & $\mathbf{1 3 - 4 - 1 - 5 - 2}$ & $\mathbf{1 3 - 2 - 1 a}$ \\
\hline \multicolumn{4}{c}{$\mathbf{w t} \%$} \\
$\mathrm{FeO}$ & 0.16 & 0.00 & 0.16 \\
$\mathrm{MnO}$ & 0.25 & 0.22 & 0.27 \\
$\mathrm{MgO}$ & 0.07 & 0.00 & - \\
$\mathrm{CaO}$ & 53.65 & 55.29 & 51.32 \\
$\mathrm{SrO}$ & 2.07 & 0.11 & 2.15 \\
\hline \multicolumn{4}{c}{ Formulae on the basis of 1 cation } \\
$\mathrm{Fe}$ & 0.002 & - & 0.002 \\
$\mathrm{Mn}$ & 0.004 & 0.003 & 0.004 \\
$\mathrm{Mg}$ & 0.002 & - & - \\
$\mathrm{Ca}$ & 0.957 & 0.986 & 0.972 \\
$\mathrm{Sr}$ & 0.020 & 0.001 & 0.022 \\
\hline
\end{tabular}


Celestine is the only accessory mineral that was analysed $\left(\mathrm{SO}_{3}=43.42 \mathrm{wt} \% ; \mathrm{BaO}=0.35 \mathrm{wt} \%\right.$; $\mathrm{CaO}=0.17 \mathrm{wt} \% ; \mathrm{SrO}=56.45 \mathrm{wt} \%$ ), and its occurrence together with barite and $\mathrm{Fe}-\mathrm{Cu}$-sulphides indicate high $\mathrm{S}$ fugacity of the system during crystallization of the carbonatite.

Baddeleyite occurs as tiny angular grains of 10-60 $\mu \mathrm{m}$ size as numerous inclusions in garnet (Figure 2f). Baddeleyite is a characteristic mineral of carbonatite-ultramafic intrusions worldwide, indicative of the Si-undersaturated environment during formation of such rocks [29]. Zircon formed apparently during late Si-saturated stages.

Table 2. Chemical analyses of pyroxene and amphibole from Breivikbotn carbonatite.

\begin{tabular}{|c|c|c|c|c|c|c|c|c|c|c|}
\hline \multirow{2}{*}{$\begin{array}{l}\text { Mineral } \\
\text { Sample }\end{array}$} & \multicolumn{5}{|c|}{ Pyroxene } & \multicolumn{5}{|c|}{ Amphibole } \\
\hline & $13-4$ & $13-2$ & $13-3$ & $13-3 a$ & $13-3 b$ & $13-4 a$ & $13-4 b$ & $13-2$ & $13-3 a$ & $13-3 b$ \\
\hline & \multicolumn{10}{|c|}{ wt $\%$} \\
\hline $\mathrm{SiO}_{2}$ & 49.74 & 50.99 & 48.47 & 51.16 & 51.91 & 37.90 & 37.46 & 39.33 & 39.14 & 39.28 \\
\hline $\mathrm{Al}_{2} \mathrm{O}_{3}$ & 3.18 & 3.44 & 4.97 & 3.70 & 3.26 & 12.32 & 12.95 & 11.72 & 12.98 & 12.76 \\
\hline $\mathrm{TiO}_{2}$ & 0.49 & 0.54 & 1.02 & 0.45 & 0.34 & 1.37 & 1.31 & 1.16 & 1.12 & 1.25 \\
\hline $\mathrm{FeO}$ & 17.75 & 14.16 & 14.16 & 13.45 & 12.62 & 25.61 & 24.30 & 21.18 & 19.89 & 19.52 \\
\hline $\mathrm{MnO}$ & 0.85 & 0.69 & 0.92 & 0.60 & 0.60 & 1.02 & 0.99 & 0.89 & 1.01 & 0.92 \\
\hline $\mathrm{MgO}$ & 6.47 & 7.59 & 7.06 & 7.65 & 8.15 & 5.26 & 4.98 & 7.62 & 7.64 & 7.72 \\
\hline $\mathrm{CaO}$ & 17.33 & 18.59 & 20.59 & 17.86 & 18.91 & 9.04 & 9.86 & 9.85 & 10.47 & 10.36 \\
\hline $\mathrm{Na}_{2} \mathrm{O}$ & 4.17 & 3.59 & 2.66 & 4.33 & 3.73 & 3.75 & 3.50 & 2.85 & 3.17 & 3.32 \\
\hline $\mathrm{K}_{2} \mathrm{O}$ & - & - & - & - & - & 2.21 & 2.24 & 1.96 & 2.28 & 2.06 \\
\hline $\mathrm{ZnO}$ & - & - & - & - & - & 0.09 & 0.10 & 0.07 & 0.09 & 0.06 \\
\hline \multirow[t]{2}{*}{ Total } & 99.98 & 99.59 & 99.85 & 99.20 & 99.51 & 98.57 & 97.66 & 96.62 & 97.80 & 97.25 \\
\hline & \multicolumn{5}{|c|}{ apfu (4 cations) } & \multicolumn{5}{|c|}{ apfu ( 23 oxygen atoms) } \\
\hline $\mathrm{Si}$ & 1.882 & 1.923 & 1.838 & 1.921 & 1.946 & 6.031 & 5.993 & 6.215 & 6.100 & 6.135 \\
\hline $\mathrm{Al}(\mathrm{iv})$ & 0.118 & 0.077 & 0.162 & 0.079 & 0.054 & 1.969 & 2.007 & 1.785 & 1.900 & 1.865 \\
\hline $\mathrm{Al}(\mathrm{vi})$ & 0.024 & 0.076 & 0.060 & 0.084 & 0.090 & 0.342 & 0.434 & 0.398 & 0.485 & 0.484 \\
\hline $\mathrm{Al}($ tot $)$ & 0.142 & 0.153 & 0.222 & 0.164 & 0.144 & 2.311 & 2.442 & 2.183 & 2.385 & 2.349 \\
\hline $\mathrm{Ti}$ & 0.014 & 0.015 & 0.029 & 0.013 & 0.010 & 0.164 & 0.158 & 0.138 & 0.132 & 0.146 \\
\hline $\mathrm{Fe}^{3+}$ & 0.373 & 0.233 & 0.238 & 0.285 & 0.216 & - & - & - & - & - \\
\hline $\mathrm{Fe}^{2+}$ & 0.189 & 0.213 & 0.211 & 0.137 & 0.180 & 3.408 & 3.251 & 2.800 & 2.592 & 2.550 \\
\hline $\mathrm{Mn}$ & 0.027 & 0.022 & 0.030 & 0.019 & 0.019 & 0.138 & 0.134 & 0.119 & 0.133 & 0.122 \\
\hline $\mathrm{Mg}$ & 0.365 & 0.427 & 0.399 & 0.428 & 0.455 & 1.247 & 1.187 & 1.794 & 1.774 & 1.797 \\
\hline $\mathrm{Ca}$ & 0.703 & 0.751 & 0.837 & 0.718 & 0.759 & 1.541 & 1.689 & 1.667 & 1.749 & 1.733 \\
\hline $\mathrm{Na}$ & 0.306 & 0.262 & 0.196 & 0.315 & 0.271 & 1.158 & 1.084 & 0.874 & 0.959 & 1.005 \\
\hline $\mathrm{K}$ & - & - & - & - & - & 0.448 & 0.456 & 0.394 & 0.453 & 0.411 \\
\hline
\end{tabular}


Table 3. Chemical analyses of garnet and titanite from Breivikbotn carbonatite.

\begin{tabular}{|c|c|c|c|c|c|c|c|c|c|c|c|c|}
\hline \multirow{2}{*}{$\begin{array}{l}\text { Mineral } \\
\text { Sample }\end{array}$} & \multicolumn{9}{|c|}{ Garnet } & \multicolumn{3}{|c|}{ Titanite } \\
\hline & $\begin{array}{c}13-4 \\
\text { C }\end{array}$ & $\begin{array}{c}13-4 \\
\text { R }\end{array}$ & $13-4$ & $13-4$ & $\begin{array}{c}13-4 \\
\text { C }\end{array}$ & $\begin{array}{c}13-4 \\
\text { R }\end{array}$ & $\begin{array}{c}13-4 \\
\text { C }\end{array}$ & $\begin{array}{c}13-4 \\
\text { R }\end{array}$ & $13-1$ & $13-4$ & $13-4$ & $13-1$ \\
\hline & \multicolumn{12}{|c|}{ wt $\%$} \\
\hline $\mathrm{SiO}_{2}$ & 34.43 & 34.68 & 33.98 & 35.06 & 34.87 & 34.63 & 35.68 & 34.83 & 36.44 & 28.86 & 29.02 & 30.17 \\
\hline $\mathrm{Al}_{2} \mathrm{O}_{3}$ & 4.65 & 3.39 & 3.65 & 3.56 & 4.43 & 3.52 & 5.62 & 3.51 & 3.19 & 1.11 & 1.19 & 1.11 \\
\hline $\mathrm{TiO}_{2}$ & 3.19 & 2.88 & 2.58 & 1.53 & 2.95 & 2.06 & 1.25 & 2.63 & 2.03 & 37.23 & 38.28 & 37.19 \\
\hline $\mathrm{FeO}$ & 19.95 & 21.79 & 22.25 & 22.52 & 20.25 & 22.25 & 20.65 & 21.60 & 21.36 & 1.88 & 1.58 & 1.68 \\
\hline $\mathrm{MnO}$ & 1.28 & 1.41 & 1.48 & 1.20 & 1.10 & 1.25 & 1.70 & 1.35 & 1.25 & 0.08 & 0.06 & 0.05 \\
\hline $\mathrm{MgO}$ & 0.34 & 0.21 & 0.17 & 0.15 & 0.27 & 0.18 & 0.14 & 0.29 & 0.15 & 0.00 & 0.00 & 0.00 \\
\hline $\mathrm{CaO}$ & 32.67 & 32.87 & 31.64 & 32.76 & 32.70 & 32.19 & 32.14 & 31.63 & 32.81 & 26.79 & 27.82 & 27.92 \\
\hline $\mathrm{Na}_{2} \mathrm{O}$ & 0.16 & - & 0.22 & - & - & 0.11 & - & - & - & 0.00 & 0.00 & 0.00 \\
\hline $\mathrm{ZnO}$ & - & - & - & - & - & - & - & - & - & 0.07 & 0.00 & - \\
\hline $\mathrm{Y}_{2} \mathrm{O}_{3}$ & - & 0.17 & 0.17 & - & - & - & 0.18 & 0.15 & - & 0.91 & 0.00 & - \\
\hline $\mathrm{ZrO}_{2}$ & 0.64 & 0.29 & 0.31 & 0.35 & 0.78 & 0.42 & 0.14 & 0.76 & 0.21 & 0.69 & 0.65 & 0.53 \\
\hline $\mathrm{Yb}_{2} \mathrm{O}_{3}$ & - & 0.04 & - & - & - & - & - & - & - & - & - & - \\
\hline $\mathrm{V}_{2} \mathrm{O}_{5}$ & 0.06 & 0.06 & 0.06 & 0.06 & - & 0.06 & 0.04 & 0.04 & 0.10 & 0.00 & 0.00 & 0.17 \\
\hline $\mathrm{Nb}_{2} \mathrm{O}_{5}$ & - & - & - & - & - & - & - & - & - & 0.37 & 0.10 & 0.63 \\
\hline $\mathrm{La}_{2} \mathrm{O}_{3}$ & - & - & - & - & - & - & - & - & - & 0.12 & 0.06 & 0.26 \\
\hline $\mathrm{Ce}_{2} \mathrm{O}_{3}$ & - & - & - & - & - & - & - & - & - & 0.30 & 0.26 & 0.71 \\
\hline $\mathrm{Nd}_{2} \mathrm{O}_{3}$ & - & - & - & - & - & - & - & - & - & 0.45 & 0.33 & - \\
\hline $\mathrm{Sm}_{2} \mathrm{O}_{3}$ & - & - & - & - & - & - & - & - & - & 0.24 & 0.12 & - \\
\hline $\mathrm{Gd}_{2} \mathrm{O}_{3}$ & - & - & - & - & - & - & - & - & - & 0.36 & 0.00 & - \\
\hline \multirow[t]{2}{*}{ Total } & 99.59 & 100.23 & 98.97 & 99.70 & 99.61 & 99.16 & 99.83 & 99.19 & 99.92 & 99.45 & 99.45 & 100.40 \\
\hline & \multicolumn{9}{|c|}{ apfu (8 cations) } & \multicolumn{3}{|c|}{ apfu (3 cations) } \\
\hline $\mathrm{Si}$ & 2.862 & 2.888 & 2.863 & 2.928 & 2.906 & 2.909 & 2.949 & 2.935 & 3.031 & 0.961 & 0.956 & 0.986 \\
\hline $\mathrm{Al}$ & 0.456 & 0.333 & 0.362 & 0.350 & 0.435 & 0.349 & 0.547 & 0.349 & 0.312 & 0.043 & 0.046 & 0.043 \\
\hline $\mathrm{Ti}$ & 0.199 & 0.181 & 0.163 & 0.096 & 0.185 & 0.130 & 0.078 & 0.167 & 0.127 & 0.933 & 0.949 & 0.914 \\
\hline $\mathrm{Fe}^{2+}$ & 1.387 & 1.517 & 1.568 & 1.573 & 1.412 & 1.564 & 1.428 & 1.522 & 1.486 & 0.052 & 0.043 & 0.046 \\
\hline $\mathrm{Mn}$ & 0.090 & 0.100 & 0.106 & 0.085 & 0.077 & 0.089 & 0.119 & 0.096 & 0.088 & 0.002 & 0.002 & 0.001 \\
\hline $\mathrm{Mg}$ & 0.042 & 0.026 & 0.021 & 0.019 & 0.034 & 0.023 & 0.018 & 0.036 & 0.019 & - & - & - \\
\hline $\mathrm{Ca}$ & 2.909 & 2.933 & 2.857 & 2.931 & 2.920 & 2.898 & 2.846 & 2.855 & 2.923 & 0.956 & 0.982 & 0.978 \\
\hline $\mathrm{Na}$ & 0.026 & - & 0.036 & - & - & 0.018 & - & - & - & - & - & - \\
\hline $\mathrm{Zn}$ & - & - & - & - & - & - & - & - & - & 0.002 & - & - \\
\hline $\mathrm{Y}$ & - & 0.008 & 0.007 & - & - & - & 0.008 & 0.007 & - & 0.016 & - & - \\
\hline $\mathrm{Zr}$ & 0.026 & 0.012 & 0.013 & 0.014 & 0.032 & 0.017 & 0.006 & 0.031 & 0.008 & 0.011 & 0.010 & 0.008 \\
\hline $\mathrm{Nb}$ & - & - & - & - & - & - & - & - & - & 0.006 & 0.002 & 0.009 \\
\hline $\mathrm{V}$ & 0.003 & 0.003 & 0.003 & 0.003 & & 0.003 & 0.002 & 0.002 & 0.006 & - & - & 0.004 \\
\hline $\mathrm{La}$ & - & - & - & - & - & - & - & - & - & 0.001 & 0.001 & 0.003 \\
\hline $\mathrm{Ce}$ & - & - & - & - & - & - & - & - & - & 0.004 & 0.003 & 0.008 \\
\hline $\mathrm{Nd}$ & - & - & - & - & - & - & - & - & - & 0.005 & 0.004 & - \\
\hline $\mathrm{Sm}$ & - & - & - & - & - & - & - & - & - & 0.003 & 0.001 & - \\
\hline $\mathrm{Gd}$ & - & - & - & - & - & - & - & - & - & 0.004 & - & - \\
\hline $\mathrm{Yb}$ & - & 0.001 & - & - & - & - & - & - & - & - & - & - \\
\hline
\end{tabular}


Table 4. Chemical analyses of zeolite group minerals and "altered nepheline" from Breivikbotn carbonatite.

\begin{tabular}{|c|c|c|c|c|c|c|c|c|c|c|c|c|c|c|c|c|c|c|c|c|}
\hline \multirow{2}{*}{$\begin{array}{l}\text { Mineral } \\
\text { Sample }\end{array}$} & \multicolumn{4}{|c|}{ Natrolite } & \multicolumn{5}{|c|}{ Gonnardite } & \multicolumn{8}{|c|}{ Thomsonite-(Ca) } & \multicolumn{3}{|c|}{ Altered Nepheline } \\
\hline & $13-1$ & $\begin{array}{c}13-3 \\
*\end{array}$ & $\begin{array}{c}13-3 \\
*\end{array}$ & $\begin{array}{c}13-3 \\
*\end{array}$ & $\begin{array}{c}13-3 \\
*\end{array}$ & $\begin{array}{c}13-3 \\
*\end{array}$ & $\begin{array}{c}13-3 \\
*\end{array}$ & $\begin{array}{c}13-3 \\
*\end{array}$ & $\begin{array}{c}13-3 \\
*\end{array}$ & $13-4 a$ & $13-4$ & $13-4$ & $\begin{array}{c}14-3 \\
*\end{array}$ & $\begin{array}{c}14-3 \\
*\end{array}$ & $\begin{array}{c}14-3 \\
*\end{array}$ & $\begin{array}{c}14-3 \\
*\end{array}$ & $\begin{array}{c}14-3 \\
*\end{array}$ & $13-1$ & $13-1$ & 13-1 \\
\hline & \multicolumn{20}{|c|}{ wt $\%$} \\
\hline $\mathrm{SiO}_{2}$ & 45.22 & 46.05 & 46.35 & 45.04 & 41.28 & 39.47 & 38.85 & 40.44 & 38.40 & 36.34 & 35.58 & 34.93 & 37.28 & 37.07 & 36.84 & 37.59 & 37.54 & 49.35 & 42.87 & 41.36 \\
\hline $\mathrm{Al}_{2} \mathrm{O}_{3}$ & 20.38 & 26.46 & 27.33 & 28.36 & 30.20 & 30.50 & 30.56 & 28.89 & 30.16 & 32.06 & 31.56 & 30.36 & 29.57 & 30.23 & 30.04 & 29.54 & 29.47 & 36.67 & 42.32 & 41.09 \\
\hline $\mathrm{CaO}$ & 0.08 & 0.12 & 0.31 & 1.48 & 4.17 & 5.12 & 6.43 & 4.34 & 6.25 & 13.16 & 12.19 & 7.08 & 11.36 & 12.61 & 12.08 & 12.06 & 11.14 & 0.24 & 6.05 & 5.97 \\
\hline $\mathrm{Na}_{2} \mathrm{O}$ & 16.61 & 15.67 & 15.13 & 14.41 & 12.67 & 12.96 & 11.41 & 11.80 & 11.62 & 3.82 & 3.75 & 3.68 & 4.09 & 4.38 & 4.35 & 5.07 & 4.57 & 14.57 & 10.86 & 10.80 \\
\hline $\mathrm{K}_{2} \mathrm{O}$ & - & 0.02 & 0.03 & 0.02 & 0.03 & 0.04 & 0.02 & 0.00 & 0.02 & - & - & - & - & - & - & - & - & - & - & - \\
\hline $\mathrm{SrO}$ & - & - & - & - & - & - & - & .00 & - & 0.73 & 2.69 & 11.76 & 3.21 & 1.75 & 2.14 & 1.80 & 1.71 & - & - & - \\
\hline \multirow[t]{2}{*}{ Total } & 82.29 & 88.32 & 89.15 & 89.31 & 88.36 & 88.09 & 87.28 & 85.47 & 86.44 & 86.12 & 85.78 & 87.81 & 85.51 & 86.05 & 85.45 & 86.07 & 84.43 & 100.83 & 102.09 & 99.22 \\
\hline & \multicolumn{4}{|c|}{ apfu (7 cations) } & \multicolumn{5}{|c|}{ apfu (7 cations) } & \multicolumn{8}{|c|}{ apfu (13 cations) } & \multicolumn{3}{|c|}{ apfu (3 cations) } \\
\hline $\mathrm{Si}$ & 3.118 & 2.991 & 2.997 & 2.919 & 2.727 & 2.605 & 2.617 & 2.775 & 2.605 & 4.932 & 4.940 & 5.176 & 5.220 & 5.070 & 5.092 & 5.116 & 5.225 & 1.223 & 1.069 & 1.059 \\
\hline $\mathrm{Al}$ & 1.656 & 2.026 & 2.083 & 2.166 & 2.352 & 2.372 & 2.426 & 2.336 & 2.411 & 5.129 & 5.164 & 5.302 & 4.878 & 4.874 & 4.894 & 4.739 & 4.835 & 1.071 & 1.244 & 1.240 \\
\hline $\mathrm{Ca}$ & 0.006 & 0.008 & 0.021 & 0.103 & 0.295 & 0.362 & 0.464 & 0.319 & 0.454 & 1.914 & 1.813 & 1.123 & 1.705 & 1.848 & 1.790 & 1.759 & 1.662 & 0.006 & 0.162 & 0.164 \\
\hline $\mathrm{Na}$ & 2.220 & 1.974 & 1.897 & 1.810 & 1.622 & 1.658 & 1.490 & 1.570 & 1.528 & 1.005 & 1.009 & 1.058 & 1.109 & 1.161 & 1.166 & 1.338 & 1.232 & 0.700 & 0.525 & 0.537 \\
\hline $\mathrm{K}$ & - & 0.002 & 0.002 & 0.002 & 0.003 & 0.003 & 0.002 & 0.000 & 0.002 & - & - & - & - & - & - & - & - & - & - & - \\
\hline $\mathrm{Sr}$ & - & - & - & - & - & - & - & - & - & 0.019 & 0.073 & 0.341 & 0.088 & 0.047 & 0.058 & 0.048 & 0.047 & - & - & - \\
\hline
\end{tabular}

Note. *-mineral species were confirmed by XRPD. 


\section{Whole-Rock Compositions}

\subsection{Major Elements}

Major element concentrations of 28 rock samples (17 carbonatitic and 11 "malignite" samples) have been analysed. Representative analyses are given in Table 5, while all analyses and CIPW norms are available in the Supplementary Data Table S1.

Carbonatite has $\mathrm{SiO}_{2}$ contents in the range of 20-36 wt \% (average $31 \mathrm{wt} \%$ ), $\mathrm{Al}_{2} \mathrm{O}_{3}=2.5-15 \mathrm{wt} \%$, $\mathrm{MgO}=1.1-4.2$ wt $\%, \mathrm{CaO}=17-34$ wt $\%, \mathrm{TiO}_{2}=1.0-2.3$ wt $\%, \mathrm{Na}_{2} \mathrm{O}=1.8-6.5$ wt $\%, \mathrm{CO}_{2}=6-15.7$ wt $\%$ and $\mathrm{P}_{2} \mathrm{O}_{5}=0.27-1.44 \mathrm{wt} \%$. Relatively large variations in aluminium, sodium, phosphorous and carbon oxide reflect variable modal contents of ZGM, apatite and calcite. The high contents of $\mathrm{Fe}_{2} \mathrm{O}_{3}$ (4-9.7 wt \%) and $\mathrm{FeO}(3-7 \mathrm{wt} \%)$ can be explained by elevated contents of andradite, magnetite and possibly pyroxene. The content of $\mathrm{K}_{2} \mathrm{O}$ is low and varies from 0.27 to $1.1 \mathrm{wt} \%$ (average $0.54 \mathrm{wt} \%$ ). High LOI in several samples (2.06-5.35 wt \%) indicates on crystallization water in ZGM. The Mg\# ranges from 20-56. The CIPW composition of carbonatite is characterized by the prevalence of calcite (15-36 wt \%), nepheline (6-20 wt \%), diopside (6-29 wt \%), hedenbergite (5-16 wt \%), magnetite (6-14 wt \%) and appearance of acmite (up to $3.3 \mathrm{wt} \%$ ).

"Malignite" is characterized by $\mathrm{SiO}_{2}$ contents in the range of 35-39 wt \%, which is much lower than in true malignite worldwide, and reflects its melanocratic features. $\mathrm{Al}_{2} \mathrm{O}_{3}$ varies in the range 10-17 wt \%, $\mathrm{MgO}=0.2-1.1$ wt \%, $\mathrm{CaO}=17-26$ wt \%, $\mathrm{TiO}_{2}=0.8-2.1$ wt $\%, \mathrm{Na}_{2} \mathrm{O}=2-6$ wt \%, $\mathrm{K}_{2} \mathrm{O}=0.26-1.38$ wt \%, $\mathrm{CO}_{2}=0.8-3.35$ wt $\%$ and $\mathrm{P}_{2} \mathrm{O}_{5}=0.17-0.26$ wt \%. "Malignite" also shows elevated contents of $\mathrm{Fe}_{2} \mathrm{O}_{3}(6.7-13.6 \mathrm{wt} \%)$ and $\mathrm{FeO}$ (1.2-3.5 wt \%). The Mg\# ranges from 10-20. Compared to carbonatite, "malignite" has higher silica, iron, potassium and lower phosphorus. The CIPW norms of rock are characterized by the appearance of nepheline (9-21 wt \%), wollastonite (20-41 wt \%), diopside (1.3-8.7 wt \%), magnetite (3-10 wt \%), hematite (2-9 wt \%) and orthoclase (up to $8.2 \mathrm{wt} \%$ ).

\subsection{Trace Elements}

Trace element analyses of representative samples are given in Table 6 (the complete data set is available in the Supplementary Data Table S1). Five samples of carbonatite were analyzed by ICP-MS for a broad range of elements, while the $\mathrm{Rb}, \mathrm{Sr}, \mathrm{Y}, \mathrm{Zr}, \mathrm{Nb}$ analyses are available for the rest of the carbonatite samples and the "malignite" samples.

The carbonatite is strongly enriched in large-ion lithophile elements (LILE), particularly LREE (880-1900 ppm), Sr (2700-8900 ppm) and Ba (200-1000 ppm) (Figure 5), as compared to the primitive mantle [30]. Mantle-normalized patterns show strong to moderate negative anomalies of $\mathrm{K}, \mathrm{Pb}, \mathrm{P}$ and $\mathrm{Ti}$ (Figure 5). Compared to average calico-carbonatite, the Breivikbotn carbonatite has the lower contents of most incompatible elements, except of K, Zr and Hf. Chondrite-normalized REE patterns (Figure 6) show negative slopes $((\mathrm{La} / \mathrm{Yb}) \mathrm{n}=6-70)$, but not as steep as in "average" carbonatite. The REE patterns and the large variations in the REE content of the rocks reflect variations in the modal content of garnet, which is responsible for the accumulation of HREE. The carbonatite does not show any $\mathrm{Eu}$ anomalies $\left(\mathrm{Eu} / \mathrm{Eu}^{*}=0.9-1.1\right)$.

The "malignite" shows elevated concentrations of Sr (650-3900 ppm, average 1580), $\mathrm{Zr}$ (1050-1350 ppm, average 1230) and Nb (35-125 ppm, average 80). Compared to the carbonatite, the "malignite" is characterized by higher $\mathrm{Zr}$, but lower $\mathrm{Nb}, \mathrm{Y}$ and $\mathrm{Sr}$. 
Table 5. Representative major and minor element analyses of the Breivikbotn carbonatite and alkaline rocks (wt \%).

\begin{tabular}{|c|c|c|c|c|c|c|c|c|c|c|c|c|c|c|c|c|c|}
\hline Sample & 13_1 & $13 \_2$ & $13 \_3$ & $13 \_4$ & $13 \_5$ & B9.5 & B19.4 & B21.4 & B11.1 & H6.2 & H40.3 & H10.7 & H41.3 & H11.6 & H15.5 & H31.3 & H48.2 \\
\hline Rock & \multicolumn{10}{|c|}{ Carbonatite } & \multicolumn{7}{|c|}{ "Malignite" } \\
\hline $\mathrm{SiO}_{2}$ & 31.74 & 26.4 & 32.1 & 28.97 & 26.51 & 31.54 & 28.67 & 28.96 & 29.76 & 20.47 & 34.95 & 37.1 & 37.46 & 37.53 & 37.71 & 39.18 & 39.43 \\
\hline $\mathrm{TiO}_{2}$ & 1.73 & 1.1 & 1.86 & 1.89 & 1.51 & 0.87 & 0.99 & 0.98 & 1.62 & 1.21 & 2.01 & 1.94 & 1.59 & 1.61 & 1.39 & 1.49 & 0.83 \\
\hline $\mathrm{Al}_{2} \mathrm{O}_{3}$ & 11.7 & 3.35 & 11.27 & 14.9 & 2.46 & 13.11 & 13.82 & 13.63 & 11.71 & 6.87 & 9.72 & 11.89 & 12.91 & 12.66 & 13.74 & 13.05 & 17.35 \\
\hline $\mathrm{Fe}_{2} \mathrm{O}_{3}$ & 6.12 & 8.92 & 6.93 & 9.69 & 5.25 & 5.46 & 4.41 & 4.37 & 5.19 & 9.62 & 13.59 & 12.39 & 10.85 & 10.39 & 10.23 & 10.27 & 6.73 \\
\hline $\mathrm{FeO}$ & 7 & 6.19 & 5.74 & 5.48 & 3.63 & 4.62 & 3.46 & 3.43 & 3.64 & 6.39 & 2.79 & 2.55 & 2.96 & 3.5 & 2.86 & 2.89 & 1.16 \\
\hline $\mathrm{MnO}$ & 0.52 & 0.57 & 0.56 & 0.45 & 0.36 & 0.5 & 0.43 & 0.44 & 0.47 & 0.69 & 1.19 & 0.99 & 0.91 & 0.91 & 0.84 & 0.87 & 0.55 \\
\hline $\mathrm{MgO}$ & 2.22 & 3.98 & 2.17 & 1.1 & 4.22 & 2.33 & 1.99 & 2.13 & 2.08 & 1.49 & 0.77 & 0.49 & 1.02 & 1.08 & 0.82 & 0.92 & 0.24 \\
\hline $\mathrm{CaO}$ & 20.46 & 30.22 & 21.49 & 19.98 & 33.6 & 21.32 & 22.54 & 22.5 & 24.16 & 30.41 & 26.42 & 23.08 & 21.28 & 21.41 & 20.41 & 20.16 & 17.12 \\
\hline $\mathrm{Na}_{2} \mathrm{O}$ & 4.08 & 1.8 & 4.52 & 3.1 & 1.78 & 4.77 & 5.82 & 5.75 & 5.13 & 2.44 & 2.04 & 2.94 & 3.82 & 3.53 & 3.97 & 3.74 & 5.97 \\
\hline $\mathrm{K}_{2} \mathrm{O}$ & 1.1 & 0.41 & 0.67 & 0.41 & 0.27 & 0.56 & 0.33 & 0.33 & 0.29 & 0.27 & 0.45 & 0.77 & 0.66 & 0.77 & 0.77 & 1.16 & 1.15 \\
\hline $\mathrm{H}_{2} \mathrm{O}$ & 0.89 & 0.46 & 0.91 & 0.64 & 0.4 & - & - & - & - & - & - & - & - & - & - & - & - \\
\hline LOI & 2.94 & 0.26 & 3.83 & 5.35 & 2.06 & - & - & - & - & - & - & - & - & - & - & - & - \\
\hline $\mathrm{P}_{2} \mathrm{O}_{5}$ & 0.45 & 0.95 & 0.52 & 0.27 & 1.44 & 0.76 & 0.78 & 0.79 & 0.63 & 0.68 & 0.23 & 0.20 & 0.26 & 0.26 & 0.33 & 0.25 & 0.17 \\
\hline $\mathrm{F}$ & 0.068 & 0.086 & 0.067 & 0.042 & 0.1 & - & - & - & - & - & - & - & - & - & - & - & - \\
\hline $\mathrm{Cl}$ & 0.011 & 0.011 & 0.029 & 0.014 & 0.02 & - & - & - & - & - & - & - & - & - & - & - & - \\
\hline $\mathrm{CO}_{2}$ & 7.91 & 13.17 & 6.57 & 6.07 & 15.35 & 9.65 & 10.72 & 10.57 & 10.41 & 15.74 & 1.39 & 0.84 & 1.49 & 1.59 & 1.6 & 1.42 & 2.96 \\
\hline Total & 98.94 & 97.88 & 99.24 & 98.36 & 98.96 & 95.49 & 93.96 & 93.88 & 95.09 & 96.28 & 95.55 & 95.18 & 95.21 & 95.24 & 94.67 & 95.40 & 93.66 \\
\hline
\end{tabular}


Table 6. Representative trace elements and REE analyses of the Breivikbotn carbonatite and alkaline rocks (ppm).

\begin{tabular}{|c|c|c|c|c|c|c|c|c|c|c|c|c|c|c|c|}
\hline Sample & $13 \_1$ & $13 \_2$ & $13 \_3$ & $13 \_4$ & $13 \_5$ & B19.4 & B21.4 & B11.1 & H6.2 & H40.3 & H10.7 & H41.3 & H11.6 & H31.3 & H48.2 \\
\hline Rock & \multicolumn{9}{|c|}{ Carbonatite } & \multicolumn{6}{|c|}{ "Malignite" } \\
\hline $\mathrm{La}$ & 214.4 & 265.7 & 190.5 & 150.4 & 470.2 & - & - & - & - & - & - & - & - & - & - \\
\hline $\mathrm{Ce}$ & 449.7 & 516.8 & 421.8 & 341.1 & 930.9 & - & - & - & - & - & - & - & - & - & - \\
\hline $\operatorname{Pr}$ & 49.2 & 51.8 & 47.6 & 39 & 96.4 & - & - & - & - & - & - & - & - & - & - \\
\hline $\mathrm{Nd}$ & 189.6 & 174.4 & 209.4 & 169.7 & 324.2 & - & - & - & - & - & - & - & - & - & - \\
\hline $\mathrm{Sm}$ & 40 & 25.3 & 49.4 & 42.4 & 56.2 & - & - & - & - & - & - & - & - & - & - \\
\hline $\mathrm{Eu}$ & 12.1 & 6.66 & 16 & 13.9 & 15.1 & - & - & - & - & - & - & - & - & - & - \\
\hline $\mathrm{Gd}$ & 29.7 & 19.8 & 35.7 & 31.1 & 42.5 & - & - & - & - & - & - & - & - & - & - \\
\hline $\mathrm{Tb}$ & 4.86 & 2.2 & 6.87 & 6.06 & 5.77 & - & - & - & - & - & - & - & - & - & - \\
\hline Dy & 24.5 & 7.83 & 35.4 & 31.9 & 23.7 & - & - & - & - & - & - & - & - & - & - \\
\hline Ho & 4.57 & 1.26 & 6.79 & 6.32 & 4.12 & - & - & - & - & - & - & - & - & - & - \\
\hline $\mathrm{Er}$ & 12.5 & 2.95 & 18.9 & 17.2 & 9.17 & - & - & - & - & - & - & - & - & - & - \\
\hline $\mathrm{Tm}$ & 1.84 & 0.37 & 2.8 & 2.58 & 1.14 & - & - & - & - & - & - & - & - & - & - \\
\hline $\mathrm{Yb}$ & 12.7 & 2.59 & 19.2 & 18.3 & 7.14 & - & - & - & - & - & - & - & - & - & - \\
\hline $\mathrm{Lu}$ & 1.87 & 0.43 & 2.88 & 2.72 & 0.97 & - & - & - & - & - & - & - & - & - & - \\
\hline $\mathrm{Y}$ & 111.7 & 30.8 & 149.8 & 148.3 & 84 & 30 & 32 & 124 & 28 & 43 & 60 & 46 & 44 & 42 & 14 \\
\hline Ta & 3.23 & 0.8 & 3.27 & 4.19 & 18 & - & - & - & - & - & - & - & - & - & - \\
\hline $\mathrm{Nb}$ & 111.2 & 20.7 & 106.3 & 124 & 231.4 & 188 & 187 & 136 & 42 & 88 & 103 & 78 & 85 & 92 & 34 \\
\hline Hf & 13.7 & 8.05 & 19.9 & 17.9 & 9.84 & - & & - & - & - & - & - & - & - & - \\
\hline $\mathrm{Zr}$ & 492.5 & 363.2 & 696.7 & 716 & 473.1 & 493 & 505 & 840 & 616 & 1359 & 1350 & 1133 & 1137 & 1145 & 1043 \\
\hline $\mathrm{Sr}$ & 4735 & 5803 & 3290 & 8856 & 4656 & 6169 & 6173 & 3780 & 8985 & 645 & 958 & 1211 & 1235 & 1505 & 3993 \\
\hline $\mathrm{Rb}$ & 16.4 & 5.82 & 10 & 5.23 & 6.41 & bd & $\mathrm{bd}$ & bd & $\mathrm{bd}$ & 8 & 10 & 6 & 8 & 12 & 9 \\
\hline $\mathrm{Ba}$ & 618.5 & 638.4 & 204.7 & 178.2 & 1003 & - & - & - & - & - & - & - & - & - & - \\
\hline $\mathrm{U}$ & 3.46 & 0.8 & 3.99 & 3.13 & 1.86 & - & - & - & - & - & - & - & - & - & - \\
\hline Th & 12.7 & 5.63 & 13.4 & 9.43 & 25.8 & - & - & - & - & - & - & - & - & - & - \\
\hline $\mathrm{Pb}$ & 4.17 & 1.86 & 3.53 & 3.2 & 2.81 & - & - & - & - & - & - & - & - & - & - \\
\hline Mo & 5.02 & 1.1 & 8.9 & 13.8 & 0.62 & - & - & - & - & - & - & - & - & - & - \\
\hline Cs & 0.16 & 0.016 & 0.11 & 0.02 & 0.091 & - & - & - & - & - & - & - & - & - & - \\
\hline
\end{tabular}




\section{Discussion}

\subsection{Petrographical Classification of the Breivkbotn Carbonatite and Alkaline Rocks}

The recommendations for the classification of carbonatites by the IUGS Sub-commission on the Systematics of Igneous Rocks [31-33] defined carbonatites as "igneous rocks, intrusive as well as extrusive, which contain more than $50 \%$ by volume of carbonate minerals". The samples of the Breivikbotn carbonate rocks studied here contain 20-50 vol. \% of carbonate mineral. Strictly speaking the rocks should be referred to as calcitic ijolites, i.e., igneous rocks containing between 10 and $50 \%$ of igneous calcite, with additional other primary minerals, such as pyroxene and nepheline. Nevertheless, the rock is extremely heterogeneous with proportions of carbonate in parts close to the classification boundary at 50 vol. \% (e.g., sample 13-3-1, see Figure 1). In terms of the IUGS chemical classification, the rock can be referred to as silicocarbonatite if the $\mathrm{SiO}_{2}$ content of the rock exceeds $20 \%$. For this reason, we prefer to name the Breivikbotn carbonatite-like rocks as nepheline-diopside-calcite-carbonatite, or for simplicity, silicocarbonatite.

Nepheline is an unusual and rare mineral in classic carbonatite complexes world-wide. Nevertheless nepheline-bearing carbonatites have been reported from a number of carbonatite localities; e.g., Laacher See, Germany and Alnø, Sweden (both mentioned in [34]), Fen [35] and Lillebukt [36] in Norway, Chilwa Island and Kangankunde, Malawi [37], Budeda Hill and Homa Bay, Uganda [38,39], Walloway, Australia [40], Dicker Willem, Namibia [41], and in Ilmeny-Vishnevogorsky, Urals, Russia [42] and from other Russian occurrences (summarized by [43]. In addition, other carbonatites contain natrolite, analcime or cancrinite, formed by breakdown of nepheline; e.g., Oka, Canada [44]; Legetet Hills, Kenya, Nachendezwaya, Tanzania, Tororo and Bukusu, Uganda (all summarized by [34]). On the basis of this distribution, and the petrographic and mineralogical evidence for the above described localities, it is possible to infer that nepheline-bearing carbonatites are often associated with the "nephelenitic-clan" rather than with the "melilititic-clan" carbonatites (using the terminology of [45]).

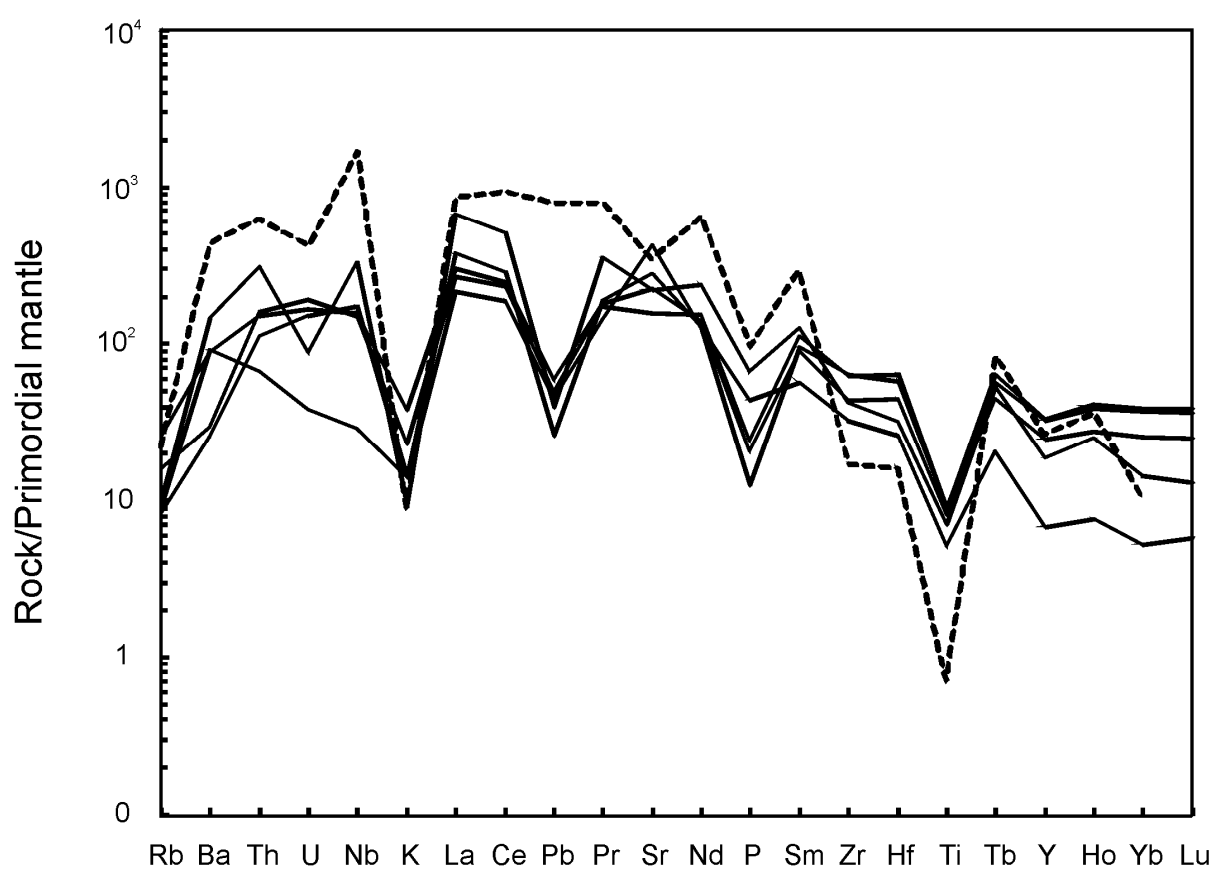

Figure 5. Mantle normalized incompatible elements patterns of silicocarbonatite from Breivikbotn occurrence. Curve for average carbonatite [32] is dotted and shown for reference. Primordial mantle composition is taken from [30]. 


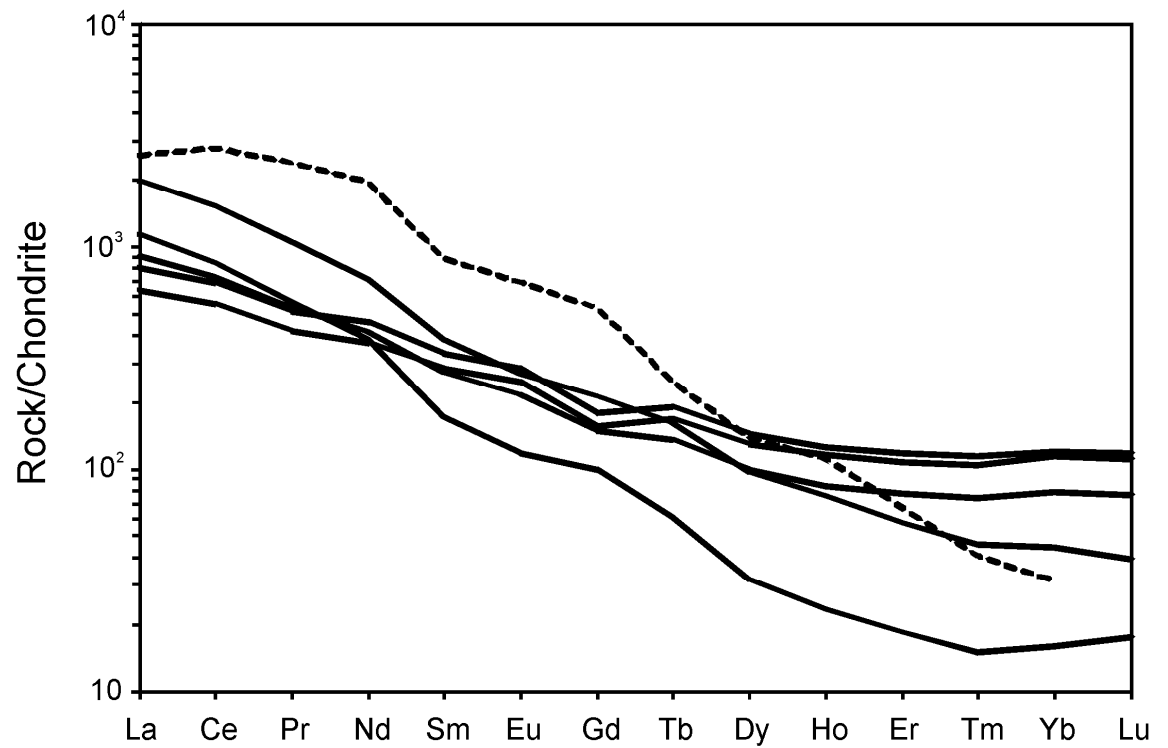

Figure 6. Chondrite normalized REE patterns of the silicocarbonatite from Breivikbotn. Curve for average carbonatite [32] is dotted and shown for reference. Chondrite composition is taken from [30].

The "malignite" from the Breivikbotn occurrence has an unusual mineralogical composition among magmatic rocks. Therefore, the classification based on the chemical composition was applied. Based on the $\mathrm{SiO}_{2}$ and $\mathrm{Na}_{2} \mathrm{O}+\mathrm{K}_{2} \mathrm{O}$ contents, the rock belongs to the clans of melilitolite or ultramafic foidolite. The last clan include melteigite, jacupirangite, ijolite, urtite and missurite, and the Na-rich $(\mathrm{Na}>\mathrm{K})$ and melanocratic varieties of the clan are comparable to the rock discussed here, namely melteigite and jacupirangite. Furthermore, the low $\mathrm{MgO}$ and relatively high $\mathrm{Al}_{2} \mathrm{O}_{3}$ of the Breivikbotn rock suggest that it could be classified as melteigite, but the elevated $\mathrm{CO}_{2}$ content $(0.8-3.4 \mathrm{wt} \%)$ justify that the rock is referred to as a carbonated melteigite. Broadly speaking, it can be stated that Breivikbotn "malignite" crystallized from a carbonated foidite melt.

Thus, the Breivikbotn occurrence provides good field material for studying the genetic link between carbonatite and foidite magma (i.e., the derivation of carbonatite magma, either by liquid immiscibility or crystal fractionation from carbonated foidite).

\subsection{Geochemical Constraints on Primary Melts, Magma Evolution and Geodynamic Setting of Breivikbotn Complex}

The proposed origins of carbonatites associated with silicate alkaline rocks include three main processes: (1) direct melting from carbonate-rich mantle peridotite or wehrlite [46-49]; (2) low-pressure liquid immiscibility from parental nephelinite (e.g., [50]); (3) extensive crystal fractionation from carbonated alkaline silicate magmas, i.e., carbonated nephelinite or melilitite [48,51-53].

Robins [36] suggested that the primary Breivikbotn carbonatite melt was derived from carbonated nephelinite magma through liquid immiscibility. According to the model of Robins [36], nephelinite magma fractionated through mela-phonolite magma to «malignite» and phonolite (yielding nepheline syenite), and through trachyte magma to alkali syenite. Parts of the model are questionable because of its complexity, and the absence at the outcrops of a number of hypothetical magmatic phases. Moreover, if the model were correct, it would be expected that the Breivikbotn carbonatitic and alkaline rocks contain significantly more highly incompatible HFS elements than nephelinite [50]. It is therefore clear that neither liquid immiscibility nor fractional crystallization can explain the formation of the studied rocks from primary nephelinite melt. We consider it more likely that the primary melt of the studied rocks corresponds to "malignite" or carbonated melteigite. 
For the Breivikbotn case, direct melting of silicocarbonatite from carbonate-rich mantle rock seems unlikely because of: (1) low \#Mg (17-56, average 37), (2) the association of carbonatite and alkaline silicate rocks in outcrops, (3) through this process, Mg-carbonate would be expected to dominate.

The derivation of melt from carbonated foidite by liquid immiscibility or crystal fractionation can be identified by geological, petrographic and mineralogical criteria, but also on the basis of trace-element geochemistry, particularly in relation to the associated silicate lithologies. The HFSE are highly informative in this respect. Data available for both the silicocarbonatitic and the alkaline silicate rocks from Breivikbotn include $\mathrm{Zr}, \mathrm{Nb}$ and $\mathrm{Y} . \mathrm{Nb}$ is a highly incompatible element, whereas $\mathrm{Zr}$ and $\mathrm{Y}$ are more compatible. Therefore, it can be expected that $\mathrm{Nb}$ partitioned into the carbonatitic melt relative to $\mathrm{Zr}$ and $\mathrm{Y}$ both during liquid immiscibility and crystal fractionation. The prevalence of $\mathrm{Nb}$ in the Breivikbotn silicocarbonatite compared to the alkaline silicate rock supports the proposed petrogenetic processes. Noteworthy, the absence of any gap in the $\mathrm{Nb}-\mathrm{Zr} / \mathrm{Nb}$ diagram (Figure 7) indicates crystal fractionation from a carbonated foidite melt (of "malignite" or melteigite composition, as proposed above). $\mathrm{Zr}$ is strongly partitioned into garnet, and would be incorporated in the early magmatic melanite in the Breivikbotn melteigite, what is reflected in $\mathrm{Y}-\mathrm{Zr} / \mathrm{Y}$ diagram (Figure 7). The role of crystal fractionation during formation of the silicocarbonatite is also supported by its relatively high $\mathrm{Th} / \mathrm{U}$ ratios (3-14; average 6.2), low $\mathrm{Zr} / \mathrm{Hf}(35-48 ; 41)$ and $\mathrm{Nb} / \mathrm{Ta}(13-34 ; 27)$ comparing to earlier magmatic phases [54-56]. Fractionation of zircon, titanite and clinopyroxene could explain such element distributions.
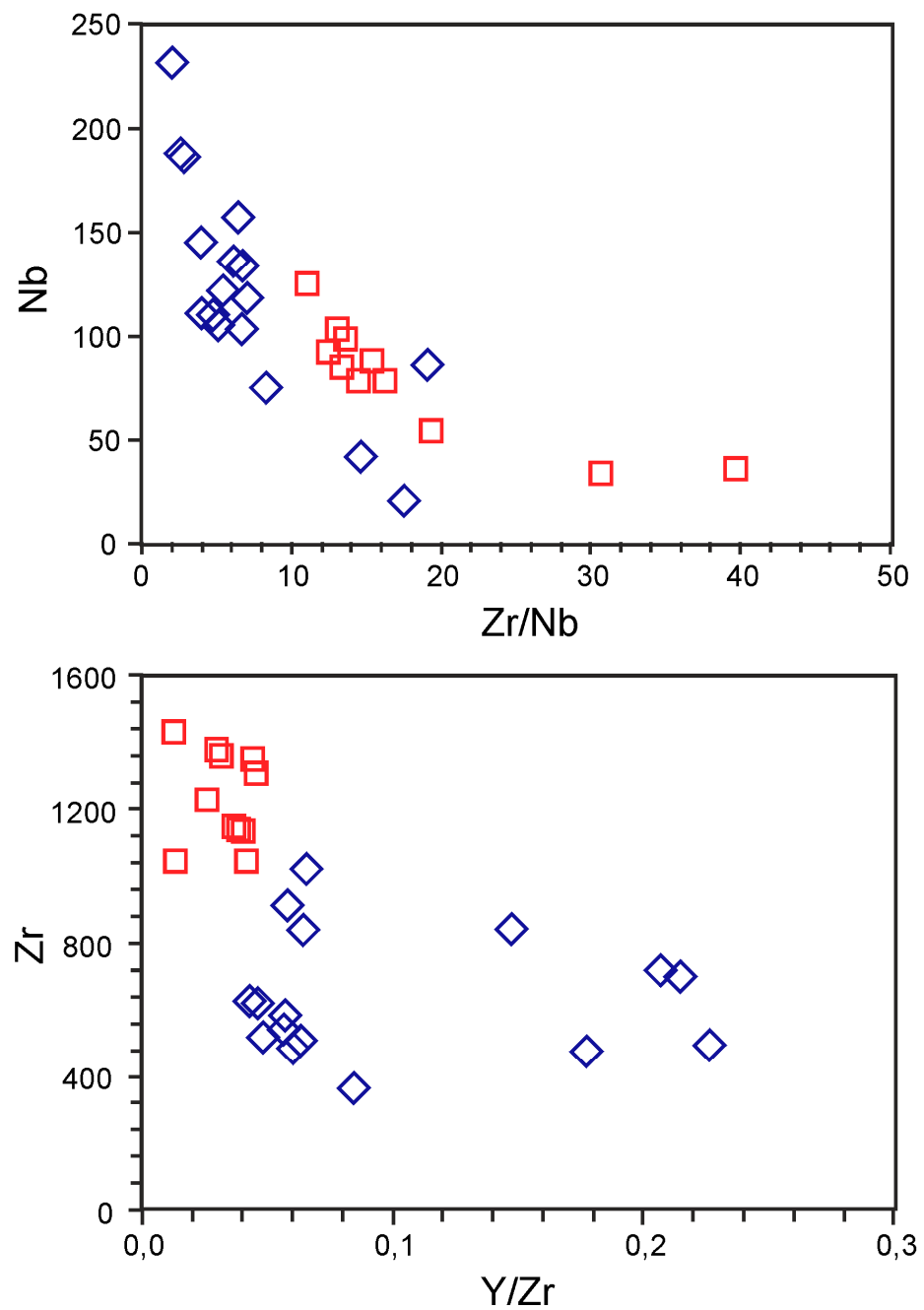

Figure 7. Selected paired trace-element ratios for the Breivikbotn silicocarbonatite and associated melteigite (blue diamonds and red squares, respectively). 
Field observations, such as gradual transitions between silicocarbonatite and melteigite, dykes of pure carbonatite cutting the melteigite, and xenoliths of melteigite in silicocarbonatite is in agreement with a process of crystal fractionation of the carbonatite from a foidite magma.

The concept of synorogenic versus extensional origin of the Seiland igneous province (see above) can also be addressed using geochemical data. Trace element concentrations provide important information about the tectonic setting. Most carbonatites in within-plate settings, e.g., continental rifts, are characterized by high concentrations of LILE (especially Sr and Ba) and HFSE; the average values for $\mathrm{Zr}, \mathrm{Nb}, \mathrm{Hf}$ and Ta are 256.4, 308.9, 4.3 and $8.9 \mathrm{ppm}$, respectively [54]. Subduction- and collision-related carbonatites in off-craton settings have higher LILE contents, but much lower $\mathrm{Zr}, \mathrm{Nb}, \mathrm{Hf}$ and $\mathrm{Ta}$. For example, Chakhmouradian et al. [55] reported for the Eden Lake carbonatite the following values (ppm): 47-98 for $\mathrm{Zr}, 4.0$ for $\mathrm{Nb}, 1.5-2.4$ for $\mathrm{Hf}$, and 0.2 for Ta. Similar values are reported from the subduction-related carbonatites in Italy, Antarctica, north-eastern China, Northern Norway [3,6,57,58], and even much lower from collision related carbonatites in southwestern and northern China [2,4]. The Breivikbotn carbonatite with average values for $\mathrm{Sr}=5100 \mathrm{ppm}, \mathrm{Ba}=530 \mathrm{ppm}, \mathrm{Zr}=700 \mathrm{ppm}$, $\mathrm{Nb}=122 \mathrm{ppm}, \mathrm{Hf}=14 \mathrm{ppm}$, and $\mathrm{Ta}=6 \mathrm{ppm}$ has the signature of within-plate carbonatites.

\subsection{Late- to Post-Magmatic Alteration and Possible Metamorphic Overprints}

Because of the alkalic and volatile-rich character, the intrusion of silicocarbonatite resulted in the extensive fenitization that can be observed at the Breivikbotn outcrops. Moreover, the presence of late-magmatic amphibole and biotite suggests that the silicocarbonatite magma contained sufficient water to produce hydrothermal fluids during late stages of crystallization. Such deuteric fluids would be able to alter the primary mineral assemblage producing the abundant water-bearing phases. The metasomatic alteration can be considered to be the result of subsolidus autometasomatism, during which early magmatic phases reacted with residual fluids to form a suite of lower-temperature minerals such as natrolite, gonnardite, and thomsonite. Experimental studies, quantitative estimates and field observations indicate that natrolite-group and thomsonite-group zeolites formed in the temperature range of $100-200{ }^{\circ} \mathrm{C}$ [59-62].

Earlier petrographic studies have shown that ZGM could be the products of nepheline alteration. Several reactions for nepheline alteration at successive enrichment of $\mathrm{H}_{2} \mathrm{O}, \mathrm{CaO} \mathrm{Al}_{2} \mathrm{O}_{3}$ and $\mathrm{SiO}_{2}$ in hydrothermal fluid may be possible:

$$
\begin{gathered}
2 \mathrm{NaAlSiO}_{4}(\mathrm{Ne})+\mathrm{SiO}_{2}(\mathrm{aq})+2 \mathrm{H}_{2} \mathrm{O}(\mathrm{aq})=\mathrm{Na}_{2}\left(\mathrm{Si}_{3} \mathrm{Al}_{2}\right) \mathrm{O}_{10} \cdot 2 \mathrm{H}_{2} \mathrm{O}(\mathrm{Ntr}) \\
\mathrm{NaAlSiO}_{4}(\mathrm{Ne})+\mathrm{SiO}_{2}(\mathrm{aq})+\mathrm{CaO}(\mathrm{aq})+\mathrm{Al}_{2} \mathrm{O}_{3}(\mathrm{aq})+3 \mathrm{H}_{2} \mathrm{O}(\mathrm{aq})= \\
(\mathrm{Na}, \mathrm{Ca})_{2}(\mathrm{Si}, \mathrm{Al})_{5} \mathrm{O}_{10} \cdot 3 \mathrm{H}_{2} \mathrm{O}(\mathrm{Gonn}) \\
\mathrm{NaAlSiO}_{4}(\mathrm{Ne})+ \\
4 \mathrm{SiO}_{2}(\mathrm{aq})+2 \mathrm{CaO}(\mathrm{aq})+2 \mathrm{Al}_{2} \mathrm{O}_{3}(\mathrm{aq})+6 \mathrm{H}_{2} \mathrm{O}(\mathrm{aq})= \\
\mathrm{NaCa}_{2}\left(\mathrm{Al}_{5} \mathrm{Si}_{5}\right) \mathrm{O}_{20} \cdot 6 \mathrm{H}_{2} \mathrm{O}(\mathrm{Thoms})
\end{gathered}
$$

Textural evidence for replacements of natrolite by gonnardite is supported by the successive enrichment of the fluid phase by $\mathrm{H}_{2} \mathrm{O}, \mathrm{CaO}, \mathrm{Al}_{2} \mathrm{O}_{3}$ and $\mathrm{SiO}_{2}$ according to the following reaction:

$$
\begin{gathered}
\mathrm{Na}_{2}\left(\mathrm{Si}_{3} \mathrm{Al}_{2}\right) \mathrm{O}_{10} \cdot 2 \mathrm{H}_{2} \mathrm{O}(\mathrm{Ntr})+2 \mathrm{SiO}_{2}(\mathrm{aq})+2 \mathrm{CaO}(\mathrm{aq})+2 \mathrm{Al}_{2} \mathrm{O}_{3}(\mathrm{aq})+4 \mathrm{H}_{2} \mathrm{O}(\mathrm{aq})= \\
2(\mathrm{Na}, \mathrm{Ca})_{2}(\mathrm{Si}, \mathrm{Al})_{5} \mathrm{O}_{10} \cdot 3 \mathrm{H}_{2} \mathrm{O}(\text { Gonn })
\end{gathered}
$$

Ti-rich garnets can form over a wide range of temperatures and pressures. Particularly in alkaline rocks, they appear to reflect complex metasomatic reactions between earlier mafic minerals and late-stage fluids $[63,64]$. This idea is consistent with the petrographic observations from the garnet-bearing rocks of the Breivikbotn outcrops, which indicate that Ti-rich garnets formation from clinopyroxene and amphibole was possibly driven by metasomatic fluids. We suggest that these reactions either occurred as a result of alkali metasomatism in a fluid-enriched environment, or in response to a late metamorphic event coeval with the Caledonian orogeny. Metamorphic 
overprint of the Breivikbotn rocks can also explain the elevated contents of $\mathrm{Al}$ and Fe in titanite from the silicocarbonatite.

\section{Conclusions}

The Breivikbotn carbonatite-alkaline complex consists of silicocarbonatite and alkaline ultramafic rock of an unusual mineralogic composition. The silicocarbonatite is composed mainly of primary magmatic calcite, pyroxene, altered nepheline, late-magmatic amphibole, post-magmatic garnet (andradite) and zeolite group minerals. The alkaline ultramafic rock, which has a composition similar to melteigite, is composed of garnet (melanite), pyroxene, alkali feldspar and altered nepheline. Geological observations and geochemical data suggest that the melteigite is an early magmatic phase parental for the silicocarbonatite, which formed by fractional crystallization from the carbonated foidite melt.

Zeolites are the products of late/post-magmatic alteration of magmatic nepheline at low temperature $\left(<200{ }^{\circ} \mathrm{C}\right)$ by Ca-, Al- and Si-bearing hydrous fluids. The alteration of nepheline to zeolite group minerals progressed through several steps: (1) "altered nepheline", (2) natrolite, (3) gonnardite, and (4) Sr-rich thomsonite-(Ca). The main prerequisites for zeolite formation in the carbonatite complex were (1) silicocarbonatite composition of the parent magma and crystallization of nepheline, (2) fractional crystallization of primary magmas leading to fluid enrichment of residual melts/hydrothermal solutions, and (3) extensive fluid alteration of the rock at late- and post-magmatic stages.

Textural and compositional data for andradite distinctly point to its formation either due to alkali metasomatism at late-, post-magmatic stage of the Breivikbotn complex, or during the Caledonian metamorphic event.

Supplementary Materials: The following is available online at http://www.mdpi.com/2075-163X/8/11/537/s1, Table S1: Chemical composition and CIPW norms of the Breivikbotn carbonatites and alkaline rocks.

Author Contributions: Conceptualization, D.R.Z. and K.K.; Methodology, E.A.S., Y.E.S. and M.G.T.; Investigation, D.R.Z., K.K. and E.K.R.; Writing-Original Draft Preparation, D.R.Z.; Visualization, D.R.Z. and Y.E.S.

Funding: This research was funded by Russian Government grant 0231-2015-0009.

Acknowledgments: We are grateful to two anonymous referees whose comments improve the manuscript greatly.

Conflicts of Interest: The authors declare no conflict of interest.

\section{References}

1. Woolley, A.R.; Kjarsgaard, B.A. Paragenetic types of carbonatite as indicated by the diversity and relative abundances of associated silicate rocks: Evidence from a global database. Can. Mineral. 2008, 46, 741-752. [CrossRef]

2. Hou, Z.Q.; Tian, S.H.; Yuan, Z.X.; Xie, Y.L.; Yin, S.P.; Yi, L.S.; Fei, H.C.; Yang, Z.M. The Himalayan collision zone carbonatites in western Sichuan, SW china: Petrogenesis, mantle source and tectonic implication. Earth Planet. Sci. Lett. 2006, 244, 234-250. [CrossRef]

3. D'Orazio, M.; Innocenti, F.; Tonarini, S.; Doglioni, C. Carbonatites in a subduction system: The Pleistocene alvikites from Mt. Vulture (southern Italy). Lithos 2007, 98, 313-334. [CrossRef]

4. Xu, C.; Taylor, R.N.; Kynicky, J.; Chakhmouradian, A.R.; Song, W.L.; Wang, L.J. The origin of enriched mantle beneath north China block: Evidence from young carbonatites. Lithos 2011, 127, 1-9. [CrossRef]

5. Hagen-Peter, G.; Cottle, J.M. Synchronous alkaline and subalkaline magmatism during the late Neoproterozoic-Early Paleozoic Ross orogeny, Antarctica: Insights into magmatic sources and processes within a continental arc. Lithos 2016, 262, 677-698. [CrossRef]

6. Ravna, E.K.; Zozulya, D.; Kullerud, K.; Corfu, F.; Nabelek, P.I.; Janak, M.; Slagstad, T.; Davidsen, B.; Selbekk, R.S.; Schertl, H.P. Deep-seated carbonatite intrusion and metasomatism in the UHP Tromso Nappe, northern Scandinavian Caledonides-A natural example of generation of carbonatite from carbonated eclogite. J. Petrol. 2017, 58, 2403-2428. [CrossRef] 
7. Elliott, H.A.L.; Wall, F.; Chakhmouradian, A.R.; Siegfried, P.R.; Dahlgren, S.; Weatherly, S.; Finch, A.A.; Marks, M.A.W.; Dowman, E.; Deady, E. Fenites associated with carbonatite complexes: A review. Ore Geol. Rev. 2018, 93, 38-59. [CrossRef]

8. Ramsay, D.M.; Sturt, B.A.; Zwaan, K.B.; Roberts, D. Caledonides of Northern Norway. In The Caledonian Orogen: Scandinavia and Related Areas; Gee, D.G., Sturt, B.A., Eds.; Wiley: New York, NY, USA, 1985; pp. $163-184$.

9. Corfu, F.; Torsvik, T.H.; Andersen, T.B.; Ashwal, L.D.; Ramsay, D.M.; Roberts, R.J. Early Silurian mafic-ultramafic and granitic plutonism in contemporaneous flysch, Mageroy, northern Norway: U-Pb ages and regional significance. J. Geol. Soc. 2006, 163, 291-301. [CrossRef]

10. Sturt, B.A.; Pringle, I.R.; Ramsay, D.M. The Finnmarkian phase of the Caledonian Orogeny. J. Geol. Soc. Lond. 1978, 135, 597-610. [CrossRef]

11. Ramsay, D.M.; Sturt, B.A. The contribution of Finnmarkian Orogeny to the framework of the Scandinavian Caledonides. In Synthesis of the Caledonian Rocks of Britain; Fettes, D.J., Harris, A.L., Eds.; D. Reidel Publishing Company: Dordrecht, The Netherlands, 1986.

12. Sturt, B.A.; Ramsay, D.M. The alkaline complex of the Breivikbotn area, Sørøy, Northern Norway. Nor. Geol. Unders. Bull. 1965, 231, 1-142.

13. Krill, A.G.; Zwaan, B. Reinterpretation of Finnmarkian deformation on western Soroy, northern Norway. Nor. Geol. Tidsskr. 1987, 67, 15-24.

14. Roberts, R.J.; Corfu, F.; Torsvik, T.H.; Hetherington, C.J.; Ashwal, L.D. Age of alkaline rocks in the Seiland igneous province, northern Norway. J. Geol. Soc. 2010, 167, 71-81. [CrossRef]

15. Jonassen, A. Geologiske og petrologiske undersøkelser av alkaline bergarter og metasedimenter tilknyttet Breivikbotnkomplekset pa Sørøy, Vest Finnmark. Cand. Scient. Master's Thesis, University of Tromsø, Tromsø, Norway, 1996. (In Norwegian)

16. Cazes, J. Ewing's Analytical Instrumentation Handbook, 3rd ed.; Marcel Dekker: New York, NY, USA, 2005; p. 1037.

17. Govindaraju, K. 1994 compilation of working values and sample description for 383 geostandards (vol 18, pg 53, 1994). Geostand. Newsl. 1994, 18, 331. [CrossRef]

18. Chakhmouradian, A.R.; McCammon, C.A. Schorlomite: A discussion of the crystal chemistry, formula, and inter-species boundaries. Phys. Chem. Miner. 2005, 32, 277-289. [CrossRef]

19. Huggins, F.E.; Virgo, D.; Huckenholz, H.G. Titanium-containing silicate garnets. 1. Distribution of $\mathrm{Al}, \mathrm{Fe}^{3+}$, and $\mathrm{Ti}^{4+}$ between octahedral and tetrahedral sites. Am. Mineral. 1977, 62, 475-490.

20. Lupini, L.; Williams, C.T.; Woolley, A.R. Zr-rich garnet and Zr-rich and Th-rich perovskite from the Polino carbonatite, Italy. Mineral. Mag. 1992, 56, 581-586. [CrossRef]

21. Russell, J.K.; Dipple, G.M.; Lang, J.R.; Lueck, B. Major-element discrimination of titanian andradite from magmatic and hydrothermal environments: An example from the Canadian Cordillera. Eur. J. Mineral. 1999, 11, 919-935. [CrossRef]

22. Saha, A.; Ray, J.; Ganguly, S.; Chatterjee, N. Occurrence of melanite garnet in syenite and ijolite-melteigite rocks of samchampi-samteran alkaline complex, mikir hills, northeastern india. Curr. Sci. 2011, 101, 95-100.

23. Whitney, D.L.; Evans, B.W. Abbreviations for names of rock-forming minerals. Am. Mineral. 2010, 95, $185-187$. [CrossRef]

24. Blancher, S.B.; D'Arco, P.; Fonteilles, M.; Pascal, M.L. Evolution of nepheline from mafic to highly differentiated members of the alkaline series: The Messum complex, Namibia. Mineral. Mag. 2010, 74, 415-432. [CrossRef]

25. Henderson, C.M.B.; Gibb, F.G.F. Plagioclase-Ca-rich-nepheline intergrowths in a syenite from the Marangudzi complex, Rhodesia. Mineral. Mag. 1972, 38, 670-677. [CrossRef]

26. Lumpkin, G.R. Nepheline and sodalite in a barred olivine chondrule from the Allende meteorite. Meteoritics 1980, 15, 139-147. [CrossRef]

27. Ross, D.K.; Simon, J.I.; Simon, S.B.; Grossman, L. Two generations of sodic metasomatism in an Allende Type B CAI. In Proceedings of the 46th Lunar and Planetary Science Conference, The Woodlands, TX, USA, 16-20 March 2015.

28. Carswell, D.A.; Wilson, R.N.; Zhai, M. Ultra-high pressure aluminous titanites in carbonate-bearing eclogites at Shuanghe in Dabieshan, central China. Mineral. Mag. 1996, 60, 461-471. [CrossRef]

29. Mitchell, R.H. Undersaturated Alkaline Rocks: Mineralogy, Petrogenesis, and Economic Potential; Mineralogical Association of Canada, Short Courses: Quebec City, QC, Canada, 1996; Volume 24, p. 312. 
30. Sun, S.S.; McDonough, W.F. Chemical and isotopic systematics of oceanic basalts: Implications for mantle composition and processes. Geol. Soc. Lond. Spec. Publ. 1989, 42, 313-345. [CrossRef]

31. Streckeisen, A. Classification and nomenclature of volcanic-rocks, lamprophyres, carbonatites, and melilitic rocks-Recommendations and suggestions of the IUGS sub-commission on the systematics of igneous rocks. Geology 1979, 7, 331-335.

32. Woolley, A.R.; Kempe, D.R.C. Carbonatites: Nomenclature, average compositions, and element distribution. In Carbonatites: Genesis and Evolution; Bell, K., Ed.; Unwin Hyman: London, UK, 1989; pp. 1-14.

33. LeMaitre, R.W. Igneous Rocks: A classification and Glossary of Terms; Cambridge University Press: Cambridge, UK, 2002; p. 236.

34. Heinrich, E.W. The Geology of Carbonatites; Rand McNally: Chicago, IL, USA, 1966; p. 555.

35. Andersen, T. Evolution of peralkaline calcite carbonatite magma in the Fen complex, southeast Norway. Lithos 1988, 22, 99-112. [CrossRef]

36. Robins, B. The Seiland Igneous Province, N. Norway: General Geology and Magmatic Evolution. Field Trip Guidebook, Part II, IGCP Project 336. Norges Geologiske Undersøkelse Report. 1996, p. 34. Available online: http:/ / www.ngu.no/upload/Publikasjoner/Rapporter/1996/96_127.pdf (accessed on 22 September 2018).

37. Garson, M.S. Carbonatites in Malawi. In Carbonatites; Tuttle, O.F., Gittins, J., Eds.; Interscience: New York, NY, USA, 1966; pp. 33-71.

38. King, B.C.; Sutherland, D.S. The carbonatite complexes of Eastern Uganda. In Carbonatites; Tuttle, O.F., Gittins, J., Eds.; Interscience: New York, NY, USA, 1966; pp. 73-126.

39. Le Bas, M.J. Carbonatite-Nephelinite Volcanism: An African Case History; John Wiley: London, UK, 1977.

40. Nelson, D.R.; Chivas, A.R.; Chappell, B.W.; McCulloch, M.T. Geochemical and isotopic systematics in carbonatites and implications for the evolution of ocean-island sources. Geochim. Cosmochim. Acta 1988, 52, 1-17. [CrossRef]

41. Cooper, A.F.; Reid, D.L. Nepheline sovites as parental magmas in carbonatite complexes: Evidence from Dicker Willem, southwest Namibia. J. Petrol. 1998, 39, 2123-2136. [CrossRef]

42. Nedosekova, I.L.; Belousova, E.A.; Sharygin, V.V.; Belyatsky, B.V.; Bayanova, T.B. Origin and evolution of the Ilmeny-Vishnevogorsky carbonatites (Urals, Russia): Insights from trace-element compositions, and $\mathrm{Rb}-\mathrm{Sr}$, $\mathrm{Sm}-\mathrm{Nd}, \mathrm{U}-\mathrm{Pb}$, Lu-Hf isotope data. Mineral. Petrol. 2013, 107, 101-123. [CrossRef]

43. Kapustin, Y.L. The origin of early calcitic carbonatites. Int. Geol. Rev. 1986, 28, 1031-1044. [CrossRef]

44. Treiman, A.H.; Essene, E.J. The Oka carbonatite complex, Quebec-Geology and evidence for silicate-carbonate liquid immiscibility. Am. Mineral. 1985, 70, 1101-1113.

45. Mitchell, R.H. Carbonatites and carbonatites and carbonatites. Can. Mineral. 2005, 43, 2049-2068. [CrossRef]

46. Wallace, M.E.; Green, D.H. An experimental-determination of primary carbonatite magma composition. Nature 1988, 335, 343-346. [CrossRef]

47. Eggler, D.H. Carbonatites, primary melts, and mantle dynamics. In Carbonatites: Genesis and Evolution; Bell, K., Ed.; Unwin Hyman: London, UK, 1989; pp. 561-579.

48. Wyllie, P.J.; Lee, W.J. Model system controls on conditions for formation of magnesiocarbonatite and calciocarbonatite magmas from the mantle. J. Petrol. 1998, 39, 1885-1893. [CrossRef]

49. Dalton, J.A.; Wood, B.J. The compositions of primary carbonate melts and their evolution through wallrock reaction in the mantle. Earth Planet. Sci. Lett. 1993, 119, 511-525. [CrossRef]

50. Le Bas, M.J. Nephelinites and carbonatites. In Alkaline Igneous Rocks; Fitton, J.G., Upton, B.G.J., Eds.; Geological Society Special Publications; Blackwell Scientific Publications: Oxford, UK, 1987; pp. 85-94.

51. Gittins, J. The origin and evolution of carbonatite magmas. In Carbonatites: Genesis and Evolution; Bell, K., Ed.; Unwin Hyman: London, UK, 1989; pp. 580-600.

52. Gittins, J.; Jago, B.C. Differentiation of natrocarbonatite magma at Oldoinyo Lengai volcano, Tanzania. Mineral. Mag. 1998, 62, 759-768. [CrossRef]

53. Veksler, I.V.; Petibon, C.; Jenner, G.A.; Dorfman, A.M.; Dingwell, D.B. Trace element partitioning in immiscible silicate-carbonate liquid systems: An initial experimental study using a centrifuge autoclave. J. Petrol. 1998, 39, 2095-2104. [CrossRef]

54. Chakhmouradian, A.R. High-field-strength elements in carbonatitic rocks: Geochemistry, crystal chemistry and significance for constraining the sources of carbonatites. Chem. Geol. 2006, 235, 138-160. [CrossRef] 
55. Chakhmouradian, A.R.; Mumin, A.H.; Demeny, A.; Elliott, B. Postorogenic carbonatites at Eden Lake, Trans-Hudson orogen (northern Manitoba, Canada): Geological setting, mineralogy and geochemistry. Lithos 2008, 103, 503-526. [CrossRef]

56. Kogarko, L.N. Geochemistry of radioactive elements in the rocks of the Guli massif, Polar Siberia. Geochem. Int. 2012, 50, 719-725. [CrossRef]

57. Ying, J.; Zhou, X.; Zhang, H. Geochemical and isotopic investigation of the Laiwu-Zibo carbonatites from western Shandong Province, China, and implications for their petrogenesis and enriched mantle source. Lithos 2004, 75, 413-426. [CrossRef]

58. Stoppa, F.; Woolley, A.R. The Italian carbonatites: Field occurrence, petrology and regional significance. Mineral. Petrol. 1997, 59, 43-67. [CrossRef]

59. Gottardi, G. The genesis of zeolites. Eur. J. Mineral. 1989, 1, 479-487. [CrossRef]

60. Senderov, E.E.; Khitarov, N.I. Synthesis of thermodynamically stable zeolites in the $\mathrm{Na}_{2} \mathrm{O}-\mathrm{Al}_{2} \mathrm{O}_{3}-\mathrm{SiO}_{2}-\mathrm{H}_{2} \mathrm{O}$ system. Am. Chem. Soc. Adv. Chem. Ser. 1971, 101, 149-154.

61. Kristmannsdóttir, H.; Tómasson, J. Zeolite zones in geothermal areas in Iceland. In Natural Zeolites, Occurrence, Properties, and Use; Sand, L.B., Mumpton, F.A., Eds.; Pergamon: New York, NY, USA, 1978; pp. 277-284.

62. Carpenter, A.B. Graphical analysis of zeolite mineral assemblages from the Bay of Fundy area, Nova Scotia. Am. Chem. Soc. Adv. Chem. Ser. 1971, 101, 328-333.

63. Dingwell, D.B.; Brearley, M. Mineral chemistry of igneous melanite garnets from analcite-bearing volcanic-rocks, Alberta, Canada. Contrib. Mineral. Petrol. 1985, 90, 29-35. [CrossRef]

64. Gwalani, L.G.; Rock, N.M.S.; Ramasamy, R.; Griffin, B.J.; Mulai, B.P. Complexly zoned Ti-rich melanite-schorlomite garnets from Ambadungar carbonatite-alkalic complex, Deccan igneous province, Gujarat state, western India. J. Asian Earth Sci. 2000, 18, 163-176. [CrossRef]

(C) 2018 by the authors. Licensee MDPI, Basel, Switzerland. This article is an open access article distributed under the terms and conditions of the Creative Commons Attribution (CC BY) license (http:/ / creativecommons.org/licenses/by/4.0/). 